\title{
Religion-based decision making in Indian multinationals: A multi-faith study of ethical virtues and mindsets
}

\author{
Christopher Chan, PhD* \\ Associate Professor in Human Resource Management \\ School of Human Resource Management \\ York University \\ 4700 Keele Street, Toronto, Ontario, M3J 1P3, Canada \\ Tel: +1-416-736 2100 ext.30593 \\ Fax: + 1-416-736 5188 \\ E-mail: cristoph@yorku.ca \\ Honorary Research Fellow \\ Faculty of Business \\ Australian Catholic University \\ North Sydney Campus (MacKillop) \\ Level 4, 21 Berry Street, Sydney, New South Wales, 2060, Australia \\ Visiting Associate Professor \\ Institut de Gestion de Rennes \\ Université de Rennes 1 \\ 11 rue Jean Macé, 35708, Rennes, Cedex 7, France
}

\section{Subramaniam Ananthram, PhD}

Senior Lecturer and Area Head - International Business

School of Management

Curtin Business School

Curtin University

Kent St, Bentley

Western Australia, 6102

Australia

Tel: 61892661312

Fax: 61892667897

Email: S.Ananthram@curtin.edu.au

*corresponding author

Paper accepted for publication in Journal of Business Ethics (28 April 2017) 


\begin{abstract}
The convergence of India's rich cultural and religious heritage with its rapidly transforming economy provides a unique opportunity to understand how senior executives navigate the demands of the business environment within the context of their religious convictions. Forty senior executives with varying religious backgrounds and global responsibilities within Indian multinational corporations participated in this study. Drawing from virtue ethics theory and using systematic content analysis, several themes emerged for ethical virtues (empathy, sympathy, humanity, justice, fairness, temperance, integrity, transparency, governance, conscientiousness, transcendence, wisdom, moral fortitude and determination). The analysis illustrates how these deeply seated ethical virtues helped to form and refine these executives' ethical mindsets via guiding principles such as an ethical culture, environment, molding, education, commitment and leadership. In turn, these ethical mindsets influenced the executives' ethical decision-making processes. We find that these executives' ethical virtues and mindsets are inspired by their religious backgrounds. In summary, a very complex mental tug-of-war appears to takes place as these executives rationalize and negotiate unethical circumstances while being cognizant of personal religious beliefs. We contend that in a pluralistic multi-faith society such as India, it is critical for corporations to align the virtues of its senior executives with those of the corporation so that virtues are applied consistently when dealing with various stakeholders. The findings present several theoretical and practical implications, which are discussed.
\end{abstract}

\title{
Keywords
}

Religiosity, ethical virtues, ethical mindsets, ethical decision making, India

\section{Introduction}

The notion of business ethics in India continues to attract the avid attention of academics, practitioners, and various governmental and non-governmental organizations worldwide. These interests are mainly driven by a desire to understand the intricacies of conducting business, forging relationships and preventing ethical scandals in one of the world's largest and most rapidly transforming economies. According to Transparency International (2015), a global non-government organization that publishes the Corruption Perception Index, India is ranked 76 out of 167 countries and has a score of 38 out of 100 (the lower the score, the more corrupt a country is perceived to be). In terms of the Bribe Payers Index, in 2011, India was ranked 19 out of 29 countries and had a score of 7.5 out of 10 (the higher the score, the less likely that firms headquartered in that country engage in bribery abroad). Thus, there is a general view that Indian businesses could do much more to improve their public image when it comes to ethical practices. Image is especially critical as India emerges as an economic powerhouse and aims to promote the image of 'Brand India' as an ethically transparent place where indigenous and foreign multinational corporations (MNCs) can flourish. However, there remains an urgent need for business leaders to navigate the often ethically challenging terrain of India, as the business environment is known to be highly politicized and bureaucratic (Fernando, 2009). Yet, it is in the interests of executives, organizations, industry associations and the Indian government to ensure that corruption, bribery, financial irregularities, insider trading and other unethical practices continue to be stamped out to restore confidence among investors, reduce unnecessary waste, promote fairness, increase social cohesion and facilitate economic stability. 
A discourse on ethical virtues, mindsets and decision making is necessary to understand business ethics. Extant research has demonstrated that leaders (especially senior executives) often set the tone for an organization's ethical climate through the emphasis they place on important virtues (e.g., criteria for promotion, bonuses, respect, integrity and so forth) (Brown and Mitchell, 2010; Eisenbeiss, van Knippenberg and Fahrbach, 2015; Moore, 2005; Treviño, Weaver and Reynolds, 2006). For example, do senior executives feel justified in promoting a family member over a substantially more competent employee? Would they source materials from a cheaper third-party provider if aware of that provider's unsafe work environment? It is suggested that involving employees in ethical decision making (EDM) is a powerful way to have everyone internalize ethical virtues and will subsequently improve the ethical fit between senior executives and followers (Beeri, Dayan, Vigoda-Gadot and Werner, 2013; Treviño et al., 2006). In some circumstances, certain organizations have shown that involving other stakeholders in the decision-making process has led to an improvement in the overall ethical climate (Brown and Mitchell, 2010). Such intimate involvement can help individuals better perceive, interpret and internalize those ethical virtues. Thus, ethical virtues, mindsets and decision making are intricately interwoven.

Although religiosity has been studied extensively in the workplace in terms of how it influences a person's virtues, mindset and decision-making processes, little is known about how individuals rationalize and negotiate between externally imposed constraints (such as unethical practices by other stakeholders) and their belief systems (Fernando and Jackson, 2006). Because there are multiple conceptions of religiosity (e.g., tenets, overall religiousness and church attendance) (Conroy and Emerson, 2004; Weaver and Agle, 2002), we define religiosity as an individual's identification with a particular religion, adherence to some or all of its teachings, and devotion to it. Furthermore, little is currently known about how a religiously pluralistic society such as India (with a Hindu majority along with minority religious groups such as Muslims, Christians, Sikhs, Buddhists, Jains and others) seeks to live in harmony (Census of India, 2001). Thus, this study heeds the call of Srinivasan (2011, p.81) that "Any discussion on ethics in India will have to deal not just with Hindu ethics but also with the other religions like Jainism, Buddhism, Islam, Christianity, Sikhism and Zoroastrianism at a minimal level" as well as the call from Miller and Ewest (2013) to depart from asking whether religious virtues have an impact on employees and companies to instead ask in what ways are these virtues impacting organizations. Given these contentions, virtue ethics theory is deemed to be well-suited for the current study because it allows for the consideration of moral excellence in decision making in Western and non-Western contexts (Audi, 2012; Chattopadhyay, 2012; Fernando and Moore, 2015; Koehn, 2013; Lutz, 2009; Wang and Hackett, in press). The confluence of the long-standing traditions of India's cultures, religious practices and rapidly globalizing economy provides an ideal opportunity to study how Indian executives with global responsibilities handle EDM in light of their religious convictions. Moreover, identifying how these variables interplay to shape EDM in a complex and dynamic globalized business environment is imperative to further strengthen understanding of their role for decision makers in MNCs. As such, the motivation of this study is to answer the following questions. First, does religiosity influence individual executive's ethical virtues and mindsets, and if so, how? Second, is executives' EDM process affected by ethical virtues and mindsets, and if so, how?

\section{Literature review}

Virtue ethics theory 
Virtue ethics theory posits that there are desirable character traits (called virtues) that can be inculcated in individuals to facilitate EDM. Proponents of virtue ethics claim that rather than resorting and being bound to laws, rules and regulations (legal ethics), it is important to focus on what it means to be human, what types of characteristics we would like a morally upright person to have and the habits that will result in the development of the desired traits (Audi, 2012). However, for MacIntyre (2007) and Rodgers and Gago (2006), virtues are more than a set of qualities that are 'nice to have' and that include dispositions to act and feel in particular ways. MacIntyre (2007) contrasted virtues with Kantian ethics by arguing that "To act virtuously is not, as Kant was later to think, to act against inclination; it is to act from inclination formed by the cultivation of the virtues" (p.149). He also rejected utilitarianism because of its inability to "accommodate the distinction between goods internal to goods external to a practice" (MacIntyre, 2007, p.198). More importantly, because our study is framed around the multi-religious context of Indian MNCs, deontology (which lacks discussion of contexts and results) and utilitarianism (which lacks consideration of norms or virtues) would not be sufficient for a discussion of religious-based virtues (Ferrero and Sison, 2014). An emphasis in virtue ethics is to find a balance (also called the Golden Mean) between any extreme excesses and deficiencies (Sidani and Al Ariss, 2015; Sison and Fontrodona, 2013). As an illustration, the virtue of courage would represent the avoidance of rashness (an excess) and cowardice (a deficiency). Other examples of virtues that are often discussed in the extant literature include generosity, honesty, integrity, gratitude, righteousness, justice and fairness (Crossan, Mazutis and Seijts, 2013; Frémeaux and Michelson, 2011; Treviño et al., 2006). In terms of practical applications for leadership, consistent or repeated decisions signal the types of virtues or even vices that leaders hold dear in their hearts. For instance, there is obviously an incongruity when a leader continuously encourages honesty but refuses to listen to dire concerns expressed by others about the direction of the organization. So then, how are virtues developed? It is believed that through the deliberate and conscious attempt to live out the virtues, one achieves moral excellence (Arjoon, 2000; Fernando and Moore, 2015). Hence, virtue ethics theory believes that it is possible to learn, develop and acquire certain "proper" habits over time.

Virtue ethics theory has also been extended to organizations, where it is believed that a lack of organizational virtues will result in long-term detrimental effects. For example, infamous examples of corporate scandals such as those at Arthur Anderson, Enron and WorldCom are often cited to illustrate unethical behavior from a virtue ethics perspective (Audi, 2012; Pinto, Leana and Pil, 2008). Using human personality traits as a foundation and personifying an organization vis-à-vis its members, several researchers have provided some conceptual and empirical arguments for organizational level virtues. Moberg (1999) argued that certain individual personality factors could impact the flourishing of an organization and speculated that agreeableness and conscientiousness could also represent organizational virtues. Chun (2005) constructed an instrument to assess the organizational virtues of integrity, empathy, warmth, courage, conscientiousness and zeal. Albeit calling them 'Corporate Ethical Virtues', Kangas, Feldt, Huhtala and Rantanen (2014, p.169) found empirical support for the organizational virtues of "clarity, congruency of supervisors, congruency of senior management, feasibility, supportability, transparency, discussability, and sanctionability." Therefore, there appears to be a wide array of adjectives used to describe organizational virtues.

Building upon the influential work on virtues by MacIntyre (1999), various researchers have attempted to provide a more nuanced understanding of a virtuous organization. For instance, Moore (2005, p.661) proposed that a virtuous corporate character must be present to avoid 
corruption and offered a definition: "A virtuous corporate character is the seat of the virtues necessary for a corporation to engage in practices with excellence, focusing on those internal goods thereby obtainable, while warding off threats from its own inordinate pursuit of external goods and from the corrupting power of other institutions with which it engages." While money, power, fame, status and reputation might be recognized as desirable, too much attention on those external goods is believed to corrupt an organization (Beadle and Moore, 2006; Buckley, 2013; MacIntyre, 1999). Perhaps a parallel could be drawn here to St. Paul's epistle to Timothy: "Those who want to be rich are falling into temptation and into a trap and into many foolish and harmful desires, which plunge them into ruin and destruction" (The New American Bible, 2011, 1 Timothy 6:9). Furthermore, Moore (2005) expounded that corporate virtues such as fortitude, temperance, justice, prudence, integrity and constancy are essential to foster inner goods (e.g., sustainability, encouraging the pursuit of excellence, understanding that profitability or reputation (also referred to as external goods) should be balanced with sustainability and development, and having a supportive culture). Hence, the premise of cultivating virtues is then to conform the will and inclination towards virtuous behavior.

In addition to contextualizing virtues at the organizational level, proponents of MacIntyrean virtue ethics have also argued that this framework is acultural. For instance, resisting what MacIntyre (2007, p. 194) calls the "corrupting power of institutions" and the cultivation of internal goods such as "justice, courage and truthfulness" are the sine qua non for being a virtuous organization. Proponents have argued that the notion of virtue is not solely the property of Western philosophical thought, as the concept of doing the right thing or being virtuous is believed to span across cultures (Demuijnck, 2015; Koehn, 2013; Murphy, 1999). Motivated to explore the usefulness of MacIntyre's (2007) framework in another culture, Fernando and Moore (2015) found that the respondents interviewed in Sri Lanka demonstrated an understanding of the purpose of their organizations as cultivating internal goods, e.g., serving their internal and external stakeholders as well as being cognizant of the environment for the common good, and they believed that the pursuit of such internal goods first and foremost inevitably leads to external goods, such as financial performance and growth. While it is encouraging to see the potential cross-cultural applications of MacIntyrean virtue ethics, more research needs to be done in other cultural contexts.

While certain virtues are arguably universal, how these virtues are expressed may differ across cultures. To illustrate, let us consider the virtues of integrity and fairness. There may be general agreement across various cultures that these virtues are necessary for interpersonal relationships to flourish in a family unit, within an organization and in society (Brown and Mitchell, 2010; Chakraborty, 1997). However, when it comes to the issue of gift giving, which is often cited in the literature pertaining to bribery and corruption, there are often two sides to the same coin. Is gift giving considered a bribe to elicit a favorable decision by another entity or is it merely a cultural norm to exchange gifts? On the one hand, one could argue that gift giving perverts the decision-making process because it creates an expectation of reciprocity, which diminishes the integrity and fairness of the process, for example, when it comes to awarding a contract to a particular company. On the other hand, in Eastern cultures, gift giving is a ritualized gesture and may or may not be construed as a bribe (Frémeaux and Michelson, 2011). Moreover, gift giving could be seen as an expression of gratitude, and the lack of reciprocity could be viewed as poor etiquette. Arguably, if the act of gift giving is to cultivate internal goods (such as fostering relationships and goodwill), then it could be seen as a virtue. Conversely, if the intention or purpose of gift giving is to elicit a favorable response towards to the gift giver (such as the award of a contract), then it becomes 
a vice or an external good. Despite legal developments in different countries to address this slippery slope (e.g., the United States Foreign Corrupt Practices Act), ultimately, individual executives are responsible for observing the laws and foreign business etiquette. However, the utility of legal means to legislate behavior is limited, as individuals and organizations can seek innovative ways around these barriers. For instance, Ernst and Young (2014) reported that higher salaries could be paid to employees with the implicit understanding that a portion would be used for bribes, employment may be provided to certain key individuals in exchange for favors and bribes can be expensed as entertainment expenses, just to cite a few examples. As such, a more fruitful way of reducing, if not preventing, unethical behavior is to expose individuals to virtue ethics and to help them apply these in practical ways so that when faced with an ethical issue, they can reflect on what a virtuous person or organization would do in such a situation.

Despite studies extolling the various virtues in Indian society (Chakraborty, 1997; Chattopadhyay, 2012; Worden, 2003), few studies have examined these virtues empirically in India (Pandey, Gupta and Arora, 2009; Ananthram and Chan, in press). In addition, there is a noticeable lack of agreement on how these virtues may or may not derive from one's religion. While virtues may be one of many sources influencing ethical behavior, another important source that is gaining traction in the literature is religiosity, which is discussed in the following section.

\section{Religious virtues, mindsets and EDM}

Although the study of religions has traditionally and solely been a philosophical and theological pursuit, the interface between religion and the workplace is attracting the attention of scholars from various disciplines. Among the monotheist religions, the Torah, Talmud, Mishnah, Bible, Hadith and Quran have been drawn upon to illustrate how to inculcate an ethical workplace culture and EDM (Ali, Al-Aali and Al-Owaihan, 2013; Parboteeach, Hoegl and Cullen, 2007; Melé, 2015; Van Buren and Greenwood, 2013). Others scholars have expounded on the roles played by Hinduism and Buddhism in fostering business ethics (Mensah, 2014). Even as early as the beginning of the 1900s, Herring (1926) pointed out the need to maintain a humanistic workplace and to ensure that the religious needs of employees were met. Further, the pertinent influence of religions on workplace issues such as work hours, child labor, reasonable working wages, living conditions, occupational health and safety of the workers, punishment, treatment of workers and their family members, religious tolerance and social roles played by organizations were relevant at that time, just as they are still relevant in today's increasingly globalized economy (ChanSerafin, Brief and George, 2013; Davidson and Caddell, 1994).

Ethical virtues are the deep-seated, innate, core beliefs that drive an individual's behavior, particularly his or her EDM. A review of the extant literature reveals a plethora of descriptors used to represent ethical virtues. For example, Glover, Bumpus, Logan and Ciesla (1997) cite honesty, integrity, achievement, fairness, and concern for others as ethical virtues. In another study, Donlevy and Walker (2011, p.4) suggest that ethical virtues are composed of "professionalism, friendliness, hospitality, equity, efficiency, community, and liberty." Suffice to say, there is no universal agreement as to what constitute ethical virtues. Yet, in various studies in business ethics, 'ethical virtues' is used as a catchphrase as if it is ontologically consistent. This lack of universality may be a result of how different cultures attribute, interpret and emphasize different ethical virtues (Patel and Schaefer, 2009; Resick, Hanges, Dickson and Mitchelson, 2006). Also, individuals may have preferences or affinity 
for particular ethical virtues over others. Notwithstanding the ontological differences, some studies suggest that leaders who promote ethical virtues, in general, tend to encourage EDM throughout the organization (Brown and Mitchell, 2010; Treviño et al., 2006). Some believe that an ethical culture within an organization is developed through followers mirroring their leaders and that when virtues are congruent, organizational actors will act in a manner that is consistent with that of the leaders (Schaubroeck et al., 2012; Treviño et al., 2006).

Although it appears to be similar to ethical virtues, an ethical mindset refers to a state of mind, an attitude and an inclination towards behaving ethically. Similar to studies pertaining to ethical virtues, there is a barrage of ideas about what constitute ethical mindsets. To illustrate, in Issa and Pick's (2010, p.613) study, the participants indicated that "aesthetic judgment, spirituality, optimism, harmony and balance, contentment, truth telling, individual responsibility and professionalism" were important aspects of an ethical mindset. What remains confusing is that in the same study, they identify "... the existence of ethical mindsets in the Australian services sector in that participants responded positively to items that include virtues such as integrity, honesty, compassion, support, truth seeking and telling, harmony and balance amongst others. These virtues resonate with being ethical, and, in turn, maintaining an ethical mindset" (Issa and Pick, 2010, p.618). Therefore, this study appears to muddle ethical virtues and ethical mindsets. Our position is that the two concepts are related but different in that ethical virtues help to inform and form an ethical mindset. In another study, Cornelissen, Bashshur, Rode and Le Menestrel (2013) conceptualized ethical mindsets as relying on either outcome-based or rule-based ethics. Similar to ethical virtues, there is a lack of agreement among researchers with regards to the attributes of an ethical mindset, but there is some evidence that an ethical mindset promotes EDM (Beeri et al., 2013). Guided by the extant literature, the current study seeks to explore whether religiosity influences EDM. If so, we seek to investigate how individuals put their convictions into action in EDM.

As pointed out by Chan-Serafin et al. (2014, p. 1596), "To assume, by neglect, that religion does not play a role in organizational life leaves us with an incomplete organization science," there is a need to understand how religious virtues might influence EDM. For example, it might be the case that following the commandments from God or a deity that are inscribed in scriptures (such as adherence to the Golden Rule or one of its variants, integrity, respect and honesty) is so vital that employees would avoid overstretching the capabilities of their organizations to deliver a particular product or service. A review of the major religious traditions present in India reveals that many of the tenets promote similar virtues that are commonly mentioned in the secular literature. According to the Census of India (2001), Hindus, Muslims, Christians, Sikhs, Buddhists and Jains represent the largest groups in India. In addition to these religions, it is also necessary to include Zoroastrianism (Srinivasan, 2011).

Various sacred texts in Hinduism have espoused concepts of various virtues and their relations to EDM. For example, rooted in the Vedas, concepts such as Rju (straight) and Vran (crooked) are used to connote right and wrong, which gives rise to concepts of ethical and unethical practices (Chattopadhyay, 2012). Other Hindu sacred texts such as the Upanishads, Bhagavad Gita, Ramayana, Mahabharta and Brahma Sutras contain various allegories that highlight the importance of integrity, truthfulness, honesty, modesty, charity and harmony, to name just a few (Deutsch and Dalvi, 2004; Narasimhan, Bhaskar and Prakhya, 2010). The battle between good and evil is illustrated in an allegory in the Bhagavad Gita, where Prince Arjuna (who was faced with the prospect of war with his relatives, friends and teachers) had to decide whether to engage in war or not while being 
counseled by Lord Krishna (Deutsch and Dalvi, 2004). Referring to the Bhagavad Gita, which is part of the Mahabharatha (one of ancient Indian epics), Chattopadhyay (2012) argues that someone without any attachment would be able to demonstrate clear judgment and make a clear decision. Furthermore, the Bhagavad Gita teaches that because reputation and wealth are held together by ethics, it is imperative for leaders to work hard, be honest, be truthful, obey the law, respect others, live in harmony with others, be transparent and renounce negativity, inequality, selfishness, indiscipline, dishonesty, laziness, arrogance and ignorance (Muniapan, 2015). In addition, Muniapan (2015, p.242) highlights that "the Bhagavad Gita stresses that an individual leader must uplift himself [sic] by his [sic] own self and he [sic] must not let himself [sic] be weakened under any circumstances or when facing a crisis or when he [sic] makes a decision." The Upanishads, which refer to a collection of texts regarding reality, touched on virtues such as wisdom, shattering ignorance, peacefulness (exemplified by a peace chant), detachment, righteous deeds, selflessness, charity (by seeing God residing in oneself and in others), and self-control (Paramananda, 1919). According to Paramananda (1919), through the regular practice of concentration and meditation on these teachings, an individual can perceive right from wrong and accordingly make a decision. Another ancient Indian epic that has influenced ethical living and decision making is the Ramayana. It has been argued that the different characters depicted in the Ramayana exemplify different virtues. For instance, Holdrege (1991, p.25) writes that "The chief hero Rama, for example, is presented as the perfect embodiment of dharma, who is willing to sacrifice everything in order to uphold dharma. His wife Sita is depicted as the ideal woman, whose purity and unfailing devotion to her husband serve as a model for Indian women." Dharma refers to "personal duty" and "eternal law," and adhering to dharma is believed to lead to happiness and a better next life (van Nooten, 2000, p.xx). The trials and tribulations in the story and the climactic battle between Rama and King Ravana to rescue Sita, with the help of Hanuman, inform us of various virtues such as integrity (where Rama continued to live out his exile in a forest for 14 years because of an earlier promise despite Bharata's plea for him to ascend the throne), loyalty (where Hanuman pledged his loyalty to Rama and promised to search for Sita) and self-control (where Rama allowed the crow that attacked Sita to live as long as it was willing to sacrifice a part of its body) (Menon, 2004; van Nooten, 2000). There are obviously other analogies in the different writings; they are too numerous to name here. However, taken as a whole, these moral teachings allude to the key virtues that Hindu virtue ethics consider to be important and how they affect decision making.

In Islam, concepts of virtue ethics are primarily informed by the Quran, Shariah, Sunnah and the writings of different Muslim philosophers. For example, concepts such as truth, justice, integrity, generosity, patience, gratitude and charity can be found in Islamic virtue ethics (Wade, 2010; Yusof, Nor and Hoopes, 2014; Zaroug, 1999). According to Adeel (2015), who referred to the works of several Muslim philosophers, Islam emphasizes virtues such as moderation (also called temperance), knowledge, wisdom, chastity, courage, justice, fear of God, conscience, humility, benevolence and patience. Interestingly, Adeel's (2015) notion is strikingly similar to Aristotle's Golden Mean in that he argues that balance and moderation should take into account situational factors such as the "current intellectual and social conditions" (p.25). However, Ansari (1989) shares Shah Wali Allah's (a Muslim scholar based in India in the $18^{\text {th }}$ century) rejection of the virtues proposed by the Greek philosophers because they were deemed to be human-centric and opted for an independent and unique set of Islamic virtues. Thus, virtues such as "purity (taharah), reverential submission (ikhbat), magnanimity (samahah), and justice (adalah)" were preferred over wisdom, courage, temperance and justice (Ansari, 1989, p.86). Sidani and Al Ariss's (2015) treatise on AlGhazali (a Sufi philosopher and mystic) in relation to the Quran and Sunnah have 
demonstrated how Islamic virtue ethics encourage various EDM processes, for example, the ethical treatment of workers (especially fair treatment), dealings with business partners (especially exhibiting honesty and justice), interactions with customers (especially being truthful), avoidance of usury and ensuring that only reasonable profits are made. In the field of marketing and Islamic ethics, Ali and Al-Aali $(2015, \mathrm{p} .840)$ argue that a corporate decision is judged on "its contribution to society and individual welfare" and decision makers "have to be evaluated based on their intentions and the avoidance of harm to society, rather than resulting financial gains." Another practical manifestation is how business is conducted by Islamic banks, where homes are not used as collateral for a mortgage (Yusof, Nor and Hoopes, 2014). These studies show that there is a plethora of views on Islamic virtue ethics, and that some of these ethics overlap with those from other religious traditions while others are unique to Islam.

The Christian (especially Catholic) virtues, which consist of the four cardinal virtues (i.e., prudence or wisdom, justice, temperance and courage) and three theological virtues (i.e., faith, hope and charity or love), can be traced back to the Bible, Catechism and writings of the Church Fathers and various popes (Benedict XVI, 2006; Dahlsgaard, Peterson and Seligman, 2005; MacIntyre, 2007; Rodgers and Gago, 2006; The New American Bible, 2011, 1 Corinthians 13:13). Furthermore, meekness, righteousness, mercifulness, cleanliness and peacefulness can be found in the Beatitudes (The New American Bible, 2011, Matthew 5:312). Morales-Sànchez and Cabello-Medina (2013) offered several reasoned arguments as to how the cardinal virtues might lead to EDM. First, prudence is thought to heighten an individual's moral sensitivity to ethical issues, promotes sound moral judgments, increases the consistency between ethical judgments and moral standards and increases motivation to pursue a morally good decision. Second, justice is thought to be a permanent attitude and also a disposition, providing consistency in moral sensitivity, moral judgment and moral motivation, all of which ultimately affect decision making. Third, temperance (also called moderation or self-control) seeks to moderate any deficiencies and excesses and thus regulates self-serving interests when making decisions. Fourth, fortitude provides the moral courage and perseverance to pursue what is morally good in the face of ethical challenges. Although the theological virtues appear to be relevant to one's relation with God at first glance, according to Tanquerey (1930, p.458), “... we cannot cultivate Christian prudence without being guided by the light of faith, sustained by hope, and stimulated by the love of God; in like manner, faith and hope presuppose prudence, fortitude and temperance, and so it is with the other virtues." Thus, the theological virtues reinforce moral virtues and vice versa. As a whole, Christian virtue ethics have implications for EDM.

Virtues similar to those in other religious traditions can also be found in Sikhism. For example, Singh (2005, p.35) highlights the importance of "wisdom, truth, temperance, humility, courage, justice and contentment" in the Sikh religion. In addition, Singh (2000) writes about other Sikh virtues such as social concerns, charity and altruism. In terms of business ethics, Singh (2013) offers some insights into the teachings of the Sikh religion. For instance, given that discrimination is frowned upon, women are considered to be on an equal footing with men, and consequently, it would be considered unethical to discriminate based on sex. This form of anti-discrimination also extends to people of other creeds, castes, cultures and skin colors. Furthermore, the prevalence of democracy means that participatory decision making is encouraged while respecting as much as possible the differing views of various individuals. Although making a profit in and of itself is not considered to be unethical, profiteering is, however, discouraged. Related to the notion of profit is the view that money and wealth per se are not evil, but attachment to them (called maya) is considered 
to be evil, which alludes to the virtue of detachment. Singh (2013) has even equated maya to a delusional state. Given that maintaining the highest moral standards and conduct is important for individuals and society in Sikhism, Singh (2000, p. 105) argues that "Corruption in political, social and religious leaders is vehemently condemned as it hurts the common good." Hence, Sikh virtue ethics also offers some insights into how virtues influence EDM.

The noble eightfold path in Buddhism (e.g., right understanding, right thought, right speech, right action, right livelihood, right effort, right mindfulness and right concentration) also provide some ideas about the virtues that are important for Buddhists (Wade, 2010). These Buddhist virtues can be applied to the development of moral character, which gives rise to other virtues such as detachment, benevolence and understanding (Wade, 2010). Motivated by a desire to know what multi-faith business leaders in Sri Lanka considered to be 'right' decision making, Fernando and Jackson (2006) found candid admissions from the interviewees that their faiths had heavy bearing on their decision making, and this connection was featured prominently among the Buddhist executives. In particular, one respondent reasoned that in times of financial difficulty, he could not provide any increments to his employees despite a desire to do so because of the need to take into account the long-term interest of the company. In another case, an executive confided that it was important for decisions to be based on the five precepts of Buddhism, especially in a difficult decision such as terminating an employee for theft. These precepts include abstinence from killing, stealing, sexual misconduct, lying and intoxicants (Ashtankar, 2015). Moreover, the virtues of non-harming, compassion, respect and kindness might manifest as an aversion to any decision that might reduce quality of life (Marques, 2009).

Jaina virtue ethics appear to share the virtues identified by many of the previously mentioned religions while at the same time having their own unique rationales. In particular, Jainism shares certain scriptures and concepts that are found in Hinduism, e.g., the Bhagavad Gita, Karma-yoga and Dharma (Chattopadhyay, 2012; von Glasenapp, 1999). The core tenets of Jainism include the virtues of non-violence or universal love (Ahimsa), non-absolutism (Anekantavada) and non-possession or detachment (Aparigraha) (Jaini, 2004). Furthermore, virtues such as altruism, honesty, truthfulness, self-control and maintaining a spirit of renunciation are strongly encouraged (Chattopadhyay, 2012). Self-realization, mediation and taking personal responsibility for one's own actions are part of the teachings, such that the internalization of the virtues will result in the spontaneous observation of the moral rules (Tater, 2010). As in the case of Sikhism, there is no caste system in Jainism (Tater, 2010), and thus it can be inferred that any decision made should avoid discrimination. In terms of practical ethics, a layperson can pursue spiritual development by taking the following five vows: Ahimsa, Satya (telling the truth), Asteya (avoid stealing), Brahmacarya (living in chastity) and Parigraha-tyaga (contentedness and renunciation) (von Glasenapp, 1999). Arguably, these Jaina virtues have important ramifications for avoiding deceit during interactions with others, tempering greed, and maintaining conscientiousness during the decision-making process.

Finally, Zoroastrianism promotes various virtues (e.g., wisdom, knowledge, thriftiness, temperance, industriousness, moderation, altruism, charity, truthfulness, righteousness, justice, self-control, purity, generosity, benevolence, to name just a few), and some of these virtues overlap with those promoted by the other religions mentioned (Buch, 1919; Rose, 2011). Similar to Jaina virtues, there is a strong emphasis on personal responsibility such that knowledge of the teachings by Zoroaster and reason are believed to create the capacity to 
develop an ethical mindset that will allow individuals to make the right decisions (Iyer, 2009). Thus, it is unsurprising that Zoroastrians focus on right thinking, speech and actions (Iyer, 2009). Citing from the Arda Viraf, a Zoroastrian scripture that chronicles the experiences of a pious Zoroastrian's dream, Buch (1919, p.93) recounts that "A man was suspended by one leg in the darkness of hell, for a city 'was confided to him for administration, and that which was proper to do and order, was not done and not ordered.' A man's eyes were scooped out and his tongue cut away, because his 'justice, in the world, was false and he took bribes and made false decisions'." These two examples appear to allude to industriousness, charity, truthfulness, self-control and other virtues. A striking example provided by Worden (2003) is when J. N. Tata lobbied the government to not make his hydroelectric plant a monopoly, which would have given him a cost advantage for his textile mills. This example perhaps illustrates the Zoroastrian virtues of temperance, industriousness and self-control. It is evident that despite religious pluralism in India, overlapping religious virtues can be found in the major religions represented there.

\section{Methods}

\section{Data collection}

The data collection process involved the development of a comprehensive semi-structured interview schedule. As suggested by Kvale (2007), the schedule was pre-tested with a 'committee of experts' which included two Indian executives who suggested some minor modifications of the phrasing in a few questions to address issues related to vocabulary equivalence. After the questions were refined, a sample of 617 Indian MNCs with overseas operations was purposively identified from twelve cities in India. In the absence of a national, state or local government-published list of Indian MNCs, the researchers had to populate their own list purposively from cities with well-established manufacturing and service hubs. The identified firms were contacted via telephone and the senior human resource manager was provided with a briefing of the research project, including its aims, objectives and benefits. Following the approaches of Carpenter, Geletkanycz and Sanders (2004) and Nielsen and Nielsen (2011), it was also explained to the manager that a member of the top management team, i.e., someone involved directly in the strategic decision making of the firm, would need to be interviewed. Twenty-five of the contacted firms refused to participate in the study and six others backed out before the semi-structured interviews could commence. Following the initial telephone calls and reminders, 43 Indian MNEs agreed to participate in the study. All interviews were conducted over the telephone. Theoretical saturation was reached after 40 interviews when "no additional data are being found" (Glaser and Strauss, 2012, p.61). As a consequence, the remaining three scheduled interviews were not conducted. In summary, the respondents included 26 Hindus, four Muslims, two Parsis, two Christians, two Sikhs and two Jains (and two who did not identify their religious affiliation) and as such were representative of the Indian population (Census of India, 2001).

Table 1 presents a summary of the participants' background. All participants were senior executives who were part of the top management team, with direct responsibilities for strategic decision making in their respective Indian MNCs. The firms included a variety of business sectors such as information technology, manufacturing, mining, pharmaceuticals, media, fast moving consumer goods, banking, petroleum, healthcare, automotive, education and business services consulting. Sixty per cent of the participants were male. Sixty-five per cent were over 40 years of age. All participants had an undergraduate degree. Moreover, 70 per cent of the respondents had obtained a post-graduate degree and 7.5 per cent possessed a 
doctorate. Eight of the participants had pursued and completed a degree or some part of their education overseas. The participants also had extensive work experience in their firms and industries, with average position and industry tenures of over 9 years and over 19 years, respectively. Furthermore, over half of the participants had overseas work experience.

INSERT TABLE 1 ABOUT HERE

All in-depth semi-structured interviews were conducted using the same schedule of questions (Table 2). By keeping the structure of the interviews loose (i.e. semi-structured, open-ended format), several unexpected and emergent themes evolved. An experienced researcher with awareness of the Indian national and business culture performed the interviews. The interviewer applied the criteria of a successful interviewer as recommended by Kvale (1996) while conducting the interviews. First, knowledge about the themes was developed through consulting the literature. Second, the interview questions were structured to ensure smooth transition and clarity. Third, proper interview etiquette (e.g., not interrupting the interviewee and listening to them sensitively) was followed. Fourth, we remained open to new directions that the interviewees thought were important. Fifth, follow-up questions were used to probe when there were inconsistencies in the responses. Sixth, whenever and wherever appropriate, the interviewer returned to the comments and clarified the responses by re-wording them for feedback. The interviews lasted between 75 and 90 minutes in duration and were conducted in English. Permission was sought from the participants to record the interviews, and all participants provided consent. An experienced professional transcribed the interviews verbatim. Sections of transcripts were randomly chosen and checked for accuracy against the recordings by another experienced professional to ensure correctness of the transcripts. There were no discrepancies observed.

INSERT TABLE 2 ABOUT HERE

\section{Social desirability bias}

Qualitative studies that employ interview techniques and studies focused on understanding ethical issues can both elicit social desirability concerns (Brunk, 2010; Nederhof, 1985). Moreover, social desirability is more prevalent in collectivistic societies (e.g., India), where individuals are challenged by pressure to conform to social norms and conventions (Robertson and Fadil, 1999). Our study adopted seven conscious strategies to minimize social desirability bias. These strategies were implemented from the design phase through the interview phase of the data collection process. First, we ensured that the participating firms and representative executives volunteered to participate in the study. This was clearly communicated to the consenting firms and executives at the outset, and this strategy afforded both the firms and the executives a high degree of comfort with the interview process as well as with the subsequent data analysis and reporting processes. Second, it was ensured that the identities of the participating firms and executives were kept anonymous at all times so as to minimize pressure on the executives to respond in a socially desirable manner. Third, a 'committee of experts' was appointed to provide advice on the relevance, applicability, sensitivity and nuances of the questions included in the draft interview schedule (Kvale, 2007). The feedback received from the committee was incorporated into the final interview 
schedule. A fourth strategy included providing only a short brief of the research study to the participating firms and executives. The brief included an overview of the study detailing its broad aims, objectives and benefits and did not explicitly include the subject matter. A fifth strategy involved engaging an experienced interviewer with sound knowledge of Indian national and corporate culture to conduct the interviews using Kvale's (1996) strategies for a successful interviewer. It was also ensured that there was no power relationship between the interviewer and the participating executives so as to avoid any socially desirable responses (Nederhof, 1985). Our sixth strategy involved conducting one-on-one interviews in familiar and comfortable surroundings as identified by Brunk (2010), who noted in a study of brand ethicality that such a strategy reduced social desirability bias. The interviews were conducted at a time convenient to the executives and in a surrounding that they felt comfortable in. Our final strategy involved briefing the participants before the interviews so that they understood that there were no right or wrong answers to the interview questions. The interviewees were also encouraged repeatedly to utilize anecdotal evidence to support their responses whenever applicable. These strategies in combination provide confidence that social desirability bias was reduced.

\section{Data analysis and interpretation}

The interview transcripts were imported into NVivo (version 10), a software program that is widely used for the systematic processing of qualitative content analysis. Lindsay (2004, p.488) observed that NVivo can provide "more rigor and traceability" than manual coding. It also allowed emerging categories and themes to be efficiently identified. Sinkovics, Elfriede and Ghauri (2008) also support the use of software for the analysis and interpretation of qualitative interview data. A critical aspect of the study was the adoption of a dispassionate approach when it came to studying a deep-rooted issue such as faith, as suggested by ChanSerafin et al. (2013), during the analysis and interpretation stage so that we remained open to the benefits and challenges associated with religiosity in the workplace.

The interview data were analyzed using Strauss and Corbin's (1997) open coding and axial coding processes. The open coding procedure involves "the process of breaking down, examining, comparing, conceptualizing and categorizing data" (Strauss and Corbin, 1997, p.61). Under this process, terms, phrases and sentences from the transcripts were highlighted and re-stated to encapsulate the meanings (Boeije, 2010). Conceptual names were given to the identified key phrases (or 'concepts'). Next, similar concepts were grouped together under a 'category', and the categories were labeled. Strauss and Corbin (1997) noted that conceptual categories have analytical power and can be used to synthesize and clarify several events or items. The researchers adopted a non-linear process to develop a reduced number of categories from the concepts. The coding process took several iterations by oscillating between the concepts and the categories, as recommended by Silverman (2000).

We also used this iterative process to code the data independently from the transcripts and then compared the codes. The similarities and differences in coding were discussed in order to maximize inter-rater reliability (Keaveney, 1995). This technique has been used to minimize coder bias, which usually results from a single coder (Miles and Huberman, 1994). The developed concepts and categories were only finalized after several rounds of discussion between the coders, and an inter-rater reliability of 95 per cent was reached (Miles and Huberman, 1994). The researchers also utilized the relevant literature to identify emergent concepts and categories in the data, using the constant comparative method to verify and 
validate the reliability of these concepts and categories (Silverman, 2000). A sample illustration of the open coding procedure is presented in Table 3.

INSERT TABLE 3 ABOUT HERE

Pursuant to the open coding process, four categories were developed following the axial coding process (Strauss and Corbin, 1990, p.96), which involved "a set of procedures whereby data were put back together in new ways after open coding, by making connections between categories." The four categories included religiosity, ethical virtues, ethical mindsets, and EDM. These categories were then linked using a Paradigm Model (Strauss and Corbin, 1997), where linkages were established according to the relationship between them as outlined in the framework presented in Figure 1. The quotes presented here are representative of the views expressed by the executive managers in the sample.

INSERT FIGURE 1 ABOUT HERE

\section{Findings}

\section{Religiosity}

Given the salient nature of religion in shaping the lives and behaviors of many individuals, it follows that religious forces have great potential in the formation of ethical virtues and mindsets (Crossan et al., 2013). Notwithstanding the potential justification for certain vices, those who adhere to organized religions to varying degrees engage in certain prosocial behaviors (Chan-Serafin et al., 2013). For example, one executive linked religion and ethics by stating that "My religious teachings from Islam inform my behavior inside and outside my organization. It is like my conscience and a moral voice always at the back of my mind." (E31). Another executive remarked that "I am at peace when I visit temple and know of colleagues who have proclaimed to be at peace when they visit their local mosque or church or fire temple. This peace is something I cannot describe, but if I were always that peaceful, I would be more conscious of every decision I take in my life." (E37).

Other individuals who were more introspective provided rationales as to why it was important to be ethically conscious. One person (E8) referred to the Hindu teachings on Karma, where one's current state in life is a result of actions in previous lives, while the actions in this current lifetime will influence the next life and so on. Referring to the same teachings, another individual (E10) mentioned that through self-realization in terms of unethical acts and a firm resolution to abstain from such acts, one could improve one's own Karma. Another executive (E31) touched upon the importance of one's role, especially for those in a position of authority, for creating an environment in which individuals are able to realize their potential and avoid unethical behavior. These philosophical views are illustrated in the following quotes:

I think that are big philosophical so you know why are you in this world and 
what are you doing, why are you doing; probably look at Karma and other things and realize why you need to be good. I think that it has got to do a lot with inward journey and introspection. E8

As Lord Krishna says every individual is very honest and sincere. It is circumstances which leads him [sic] to this. So if we have the right environment, people will fall in line and not resort to any of these unethical practices. So if one creates an environment in the organization, the employs will fall in line. E10

I do many things to personally sharpen my ethical mindset. I meditate in the mornings which help me clear my mind. I read spiritual and self-help books that help deepen my understanding of right from wrong. I talk frequently to my Zoroastrian religious advisor who offers good advice all the time. I also practice what I preach and am willing to accept criticism even from junior workers. E32

\section{Ethical virtues}

- Empathy, sympathy and humanity

Three critical concepts (e.g., empathy, sympathy and humanity) emerged from the interview data. These concepts mainly relate to the variety of ways to connect with employees, such as "nurturing a particular individual" (E9), "friendly relations" (E11), realizing that "being senior doesn't mean that you can throw your weight around and ask the subordinate to do something that is not ethical" (E12), "make our staff very comfortable" (E14), and "win the heart of the employees" (E15). Recent studies have demonstrated the relevance of these virtues to ethical leadership and to inculcating an ethical organizational climate (Kriger, 2013; Storsletten and Jakobsen, 2015). All of the executives were very cognizant of the needs of their employees and would personally go out of their way to ensure that, wherever possible, these employees would stay with the organization for a long time. For example, the following quotes indicate the extent to which they provide unexpected benefits to their employees:

If there is an employee who wants to build his [sic] own flat or construction of his [sic] own property, or get his [sic] daughter gets married or do something like that, we definitely help them. E1

Welfare of people - this also comes from the Quran. I try and lead by example and try my best to look after my subordinates, clients and internal/external parties. E31

Even in Germany and Vietnam, we have a policy to give freedom to employees to celebrate and practice their festivals and religions. The salaries we pay in our company are higher than what others pay. We also provide benefits like health insurance, extra leave, study help as part of our vision to treat staff like family.E34

In addition to the employees, the executives attend to the needs of other stakeholders, especially their customers and suppliers. Some have even gone above and beyond the call of 
duty to personally help their stakeholders to resolve problems. These findings correspond to corporate social responsibility, where the various stakeholders' interests are met and openly communicated (Storsletten and Jakobsen, 2015). Such a level of attention requires those responsible to be mindful of stakeholders' needs. For example,

So you make sure that we listen to the customer, we regularly talk to the customers, find out if they are having any problem with our services etc and make sure that we adjust them whatever is possibly the best way. Yes, that's it; we do make sure that our customers don't go dissatisfied. Suppliers, we do treat suppliers as partners. We regularly try to upgrade their skill and also make sure that whatever they have, at times we upgrade their systems at our cost and they cover it from them over a few times, that's okay. So vendor is not important because ultimately we benefit if his systems are good. So his [sic] plant, his [sic] machinery whatever, at times we advance loan to him [sic] at easy terms so that he [sic] can upgrade his [sic] facilities to provide us better products. E20

\section{- Justice and fairness}

Most of the executives indicated that 'justice' and 'fairness' are part of the ethical virtues that they and their organizations espouse. Closely reflecting the notions of 'distributive justice' and 'social justice' that are rooted in the principle of need (Engelstad, 1997; Konow, 2001), they mentioned the importance of allocating resources based on the needs of individuals. The first executive elucidated these concepts succinctly:

So people have to be taken care of as per the cost of living index of the place in which they are employed. That is very important; otherwise there is no ethics possible. As a consumer the employees should also have the purchasing power. E1

One thing I learnt while working in the USA is to communicate well and be open and transparent. People perceive Indians are close minded and perhaps culturally they are. However my experience has led me to believe that I need to be open and fair in my dealings and subordinates and clients always respect me for that. E31

As promoted by Verdorfer, Steinheider and Burkus (2015), consistency in how people are treated and having clear organizational policies were instrumental in promoting fairness and compatible with ethical virtues. For example, one interviewee pointed out that "Consistent practice is very important; I cannot be good today and bad tomorrow. No way!" (E1). This is echoed by another executive (E32), who stated that "Consistency - in promising key deliverables and making sure they are of the same standards which are generally matched with international quality standards." In other cases, as far as the executives were concerned, people in India and overseas were treated with the same degree of fairness.

We do not treat any agency house worse or better than the other. It's very fair to every one. We really don't know whether there are any differences in the ethical principles being followed by the company in dealing with people in India and abroad. E7 
See I use only one basic rule in my business day to day interactions that I should be stick to my company policies and I should honor that under any given circumstance. I should not break or make it flexible for anybody, it has to be same throughout for end-to-end customers in India, oversees everywhere. E24

In other cases, being consistent in how they treated or dealt with others helped to avoid any favoritism. Some pertinent examples involved a government official pressuring one executive to hire certain individuals - "I tell them frankly if you want I can recommend some other industry but I will not employ him [sic], come what may" (E2), disciplining someone "If my manager has done some mistake and my front office person might be I am telling both of them different way it might happen, but both of them I am giving same treatment" (E17), and avoiding lobbying to advance one's interests - "Generally as a company we are very clear to not practice things like lobbying" (E5). Also, another interviewee indicated that complying with the local laws without compromise was part of being consistent and was vital for organizational longevity in various foreign countries:

I think the foremost is that; we must comply to the laws of the land, whether in India or overseas. We have facilities in Thailand and UAE and in South Africa already. And we have been present in these markets and some of them as early as 1995 and others from a more recent origin. That's something we go entirely by... the first and foremost principle is to not get into cases of any kind of violation of the laws of the land and the second thing what we do is to not to get into the litigation issues. E21

\section{- Temperance and integrity}

Related to ethical virtues is the awareness of one's temperance and personal integrity. These virtues take the form of avoiding any contact with someone of dubious character or background, not wavering from one's ethical principles, providing ethical leadership, and being honest at all times (Arjoon, 2000). Some of the pertinent comments regarding these issues included "If the fellow is a corrupt fellow, I cannot engage him [sic] in any services. Or if he [sic] becomes corrupt after engaging in services, that time also I have to throw him [sic] out" (E1), "I don't go to the doctor for prescribing my products" (E2), "We never lobby ... This is something that we do not do in India and also within the organization" (E5), "Every procedure, every policy is so well laid down, everything is so transparent, every directive is given so clearly that the people don't really have scope of doing anything outside it" (E7), "Whoever is in key position or you know at whatever level within the organization, I think their personal integrity level should be very, very high" (E8), and "Work with high integrity. Be honest to yourself and be honest to your employees. This leads to people trusting you more and more" (E10). Perhaps the most striking example regarding temperance and personal integrity was provided by an executive from a pharmaceutical company:

I had tried to introduce mobile hospital for the state of Jammu \& Kashmir. It was a matter of maintenance for the government. There I got the order from Chief Minister (name); he called me and said, look I want two mobile hospitals, one for Jammu and one for Srinagar. The concept of the mobile hospital was, instead of patients, the hospitals go to the patients. They liked my idea. All of a sudden the government changed and informed in conference. Then the new minister of Health wanted something out of it. I didn't 
compromise, I refused, I stick [sic] to my business ethics. I said I am working for the nation. If you feel it is good for the nation, accept it or else reject it. They didn't take any interest; I said ok I will close this chapter. E2

In addition to modeling ethical examples (also called role modeling), which is the thrust of most studies in business ethics (Jordan, Brown, Treviño, and Finkelstein, 2013), it is sometimes useful to contemplate the bad behaviors that one wishes to avoid. For example, one executive recounted and contrasted his approach and that of his brother. In particular, he mentioned how personal integrity played a vital role in generating respect and recognition within the industry, which translated to repeat businesses:

My brother also flourished by following unethical practices. He is a man of multi core facilities as compared to me. I cannot achieve that level in that way because there is a respect for me in the industry. People believe money brings respect but I don't think in that manner. If I go to any department and my bother also goes there, they will call me first and that is how they honor me and respect me. $\mathrm{E} 2$

There appeared to be a cautious approach when it came to the issue of exchanging gifts. While some individuals preferred not to accept any gifts, others understood the cultural implications of gift giving. For those who chose to accept and give gifts, there were strict guidelines set by the organizations, such as the types, virtues of the gifts and, in some cases, the need to report gifts. For instance,

We are not supposed to accept gifts. Employees do not accept gifts at all from suppliers or vendors. Every time when you have a vendor or you know, your partner coming and giving you a gift, you declare a sale to the HR department, the HR department will either tell you, yes, Okay, this is acceptable or there are certain levels of gifts that you can accept, in case it goes beyond that then you need to inform the HR and the HR takes care of that and whatever money is generated from these kinds of gifts, the associates are praised for their social responsibility activities. E12

Corporate gifts are identified and we have a standard gift and also kind of a category is defined, to whom to give this kind of gifts and whether the individual or function should accept the gift or not. So that is another aspect. Because in many companies it is normal to give gifts whether it is any kind of religious or whether it is kind of occasion, even, whatever, so there we have actually defined company principles. E4

- Transparency and governance

The themes of transparency and governance appeared in the executives' comments in relation to ethical virtues. Having transparency and good corporate governance essentially stemmed from recognizing how an organization's compliance (or lack thereof) and behaviors are easily observed by insiders and outsiders, who will either react positively or negatively to its actions (Beeri et al., 2013). Integral to ethical corporate governance is leadership, and sufficient emphasis was placed on ensuring that the organization was led by someone perceived as being ethical (Fyke and Buzzanell, 2013). In highly regulated industries, such as the health care or medical industries, there are specific and strict guidelines that are promulgated by the 
Medical Council of India, and if there were breaches, there "would be consequences" (E13). Similarly, the consequence of a lack of ethical leadership would "land the organization into a loss" (E13). This same individual mentioned the need to incorporate environmental ethics as part of an organization's governance:

Social responsibility actually involved what corporations need to do, to fall into that in an ethical behavior like yesterday I gave example of drainage of toxic chemicals into that some of the river. I mean this is something which is widely happening in India. Environmental issue they do not follow these issues which are related to the environment, they compromise on that. (E13)

Often, transparency and governance are communicated via an organization's website; one executive wrote "We have a code of conduct already put on our website and we as our normally practice taken, undertaking from all the senior management team and also internally of promising to have the best ethical practices in doing business or in governance" (E10). While organizations can often have lofty aspirations in their code of conduct, the behavior of individuals, especially executives, needs to be consistent with those aspirations, as others outside the organization often evaluate the actions of those they view as representatives. For example,

Here we saw a completely different thing because a partner company evaluated us, they asked about ethics governance and all that to become a partner. But, so we have the right things done and we got into that league, because we qualified for it, so we have the right person heading. E8

- Conscientiousness and transcendence

Typically, the executives saw conscientiousness as an important component of their ethical virtue system. Indeed, extant research has demonstrated that conscientiousness is related to EDM (Kalshoven, Den Hartog and De Hoogh, 2010). One example of conscientiousness playing a vital role is the ability to behave ethically in the face of temptation. When an interviewee's peers suggested that he manipulate the price of his products to include unreasonable markups, he refused to do so and commented, "With my customers I will always try not to cheat them. I will see to it that they will get good quality" (E5). Further, there may be occasions when individuals are confronted by an ethical dilemma; as another executive suggested, it is better to "leave it for the time being and wait for the correct time" (E2). Another feature of conscientiousness is the ability to see how various functional and operational areas of an organization fit together. As with any complex system, sometimes one or a few areas will cause a delay; instead of finding excuses, one executive decided to quickly inform the client, as illustrated in the following statement:

The product launches have responsibility from all functions because many things are involved. So that way we are responsible that we have committed some time frame that this product will be launched by this date, then I must do it by that time. And for that if I have to take resources and I am delayed, I should write to them. E3

My religion also teaches me to be friendly and haromony. The moral commandments in the holy quran also expect muslims will be fair and practice ethics which I try and do to the best of my ability. I also try not to harm anyone 
and be as kind as possible $\mathrm{E} 33$

Linked to conscientiousness is the concept of transcendence. Various religious traditions teach that there is something beyond the material world, and these executives' awareness of their actions, stemming from their religiosity, appears to influence their behavior and decisions. Several studies examining the religiosity and work interface have found the presence of productive work behaviors (Chan-Serafin et al., 2013; Dust and Greenhaus, 2013; Guillén, Ferrero and Hoffman, 2015). Two examples of executives identifying the ethical virtue of transcendence are illustrated below:

Religion and ethical values are intertwined. Why? Because the religious ideals allow individuals to transcend beyond the superficial aspects in life and focus on being in the present, being conscious, being focused. It allows you to be your own moral police. E39

You cannot be a good leader if you do not respect every individual. Even if I have conflicts at work with people, or when someone does not agree with what I have proposed, I always communicate with them my thoughts and ideas and try and justify my point of view. I never hold a grudge against someone who does not agree with me. This is one of the teachings from the Guru Granth Sahib. Sikh people are patient and tolerant and understanding of other people, their cultures, their religions, their ethnicities etc. Sikhism believes in oneness in God so we are very tolerant of others and that shows respect for other people. $\mathrm{E} 38$

- Wisdom

In line with Sternberg's (2004, p. 287) balance theory of wisdom, which is based on how individuals apply their "intelligence, creativity and knowledge" to promote the common good, many of the executives explained the importance of having the wisdom to address the ethical issues that they faced. As one executive (E2) illustrated, "If a person doesn't have a positive perception one cannot solve any problem, and practice any of the ethical principle." Another executive discussed the wisdom to know when one had done the wrong thing and taking steps to avoid the same mistake again - "In fact in my company I have seen that we have learned from past mistakes. So in case something goes wrong we try not to repeat it" (E21). Sternberg (2004) argues that wisdom is about knowing what to do in certain situations. A few interviewees touched upon 'knowledge' when dealing with customers, especially as it relates to treating them sensitively. For example,

Don't ditch and don't go back from your word. Whatever commitment we have given to customer, it should be fulfilled and as far as possible don't go legally with the customer if at all there is some kind of misunderstanding from both the sides. E9

From a finance perspective, I have to have a one track mind and ensure that the bottom line of the business is always healthy. But the health of the bottom line cannot be negatively affected by the ethical priority of the business (balancing act). E36 
According to Aristotelian philosophy, ethics and wisdom are inherently linked, and one of the hallmarks of wisdom is phronesis, which is sometimes referred to as practical wisdom or prudence (Fowers, 2003). The process normally involves an evaluation of the choices at hand so that one can make a prudent decision, which is considered to be good according to the circumstance(s). An example of phronesis that was mentioned by one particular executive involves knowing which choices in life to pursue and which to avoid. For example,

I do not get influenced by the society like in terms of materialistic things, car and other things. I am not one who likes to buy fancy cars and I am satisfied with something which I have. I make a point that I don't get into office politics and other things which puts pressure on me. So, I just get busy in doing my work. E20

- Moral fortitude and determination

In a business environment where there are morally complex issues to tackle, organizational leaders need to muster the necessary moral fortitude to promote ethical behavior. According to Hannah, Avolio and Walumbwa (2011) and Sekerka and Bagozzi (2007), in addition to helping them resist temptation, pressure or unethical behaviors, leaders' moral fortitude has a spillover effect on followers, and this cascading effect helps to instill ethical virtues in an organization. In line with this thinking, one executive in our sample mentioned the importance of a conscious perseverance in conducting one's affairs ethically at all times. Another touched upon finding ways to achieve business goals without compromising ethics through a set of guiding principles. Nevertheless, both alluded to times when it was difficult to find a balance. For instance,

We should have the perseverance and unless someone is very perseverance in life, in official life and business life, it is not possible to achieve. And so lots of gives and takes are there in business, but the only thing is that one should be very conscious. E1

It is important to be firm and resolute in your convictions even during tempestuous times. My religious principles compel me to form a moral fortress which is impenetrable. If it is broken, my moral fortitude is shaken. E33

A concept closely related to moral fortitude is the determination to make ethics part of the individual and organizational ethos. In this sense, determination is a considered decision that an individual makes as a result of weighing the pros and cons of an action, and this process also involves consideration of how an action could potentially affect others inside and outside of the organization (Sekerka and Bagozzi, 2007). Indeed, when faced with a decision, wider implications such as the long-term sustainability of the organization and the avoidance of short-term gains should be a part of that ethical thought process. For example,

If you see the way in which (Company name) has evaluated its share in the market, the way its corporate image has been created, it helps a lot. We cannot work this in a day or two. It is a story from beginning and because they follow these value that's why people respect (company name) well as (company group). E26 
If you sell those things which are not good for others it is also unethical. I only sell those things which are good for people. E2

Ethical mindsets

- Culture

The development of ethical mindsets has been shown to depend on the strength and influence of the social institutions in a society. For example, Issa and Pick (2010), Lee and Ruhe (1999) and Mensah (2014) have demonstrated that national, religious and organizational cultures play an active role in shaping individuals' philosophies about life and, subsequently, in how they form their ethical mindsets and ethical organizational cultures. In the case of the Indian executives, three main cultural influences were apparent. The first cultural influence involved organizational culture, through which acceptable and unacceptable rules of engagement were clearly communicated to everyone within the organization. The various ways in which these senior executives inculcated an ethical mindset included putting senior individuals in charge of mentoring employees in their moral responsibilities on a continuous basis (E17 and E25), communicating the organization's core values and ethics via the human resource department (E20), asking everyone to reflect on the pros and cons of what it meant to be unethical (E28), reprimanding someone without embarrassing that person in front of others (E3), and understanding the gravity of one's position and responsibilities because subordinates will tend to mirror one's behavior (E24). As two executives pointed out succinctly,

When someone joins the organization, this is when you start imbibing slowly and steadily into them; that these are the policies. This is how we are going to do our business. These are the dos and these are the don'ts. E7

I have seen companies announcing their values to the employs you know. It starts its stop down driven. And once this is done, the people will catch up and improvize on that and move forward. E10

Other cultural influences via national and religious institutions were also apparent in the feedback provided by the executives. For instance, alluding to the various sages in history, one individual commented on the importance of self-reflection and on how such an introspective approach helped to focus the mind on ethical issues. Introspection also has the capacity to add praxis to help everyone turn an ethical mindset into second nature, which is in line with the idea promulgated in virtue ethics. An example included

So there is a method which we follow which I think many life teachers teach and that is something called as daily introspection which means that before we retire to bed, you go through everything that happened from morning to night, nothing like office work and home and all. E8

I had good childhood, stable family, ethical education from schools and universities. I also update myself with readings on ethics and also religious teachings which are related to ethical practices. I also discuss with my colleagues when in doubt about something and we can brainstorm and decide on right course of action. Because I am the CFO, my decisions impact 
everyone in the firm so I have to have the right ethical frame before taking critical decisions. E31

I follow the golden rule stated by my Christian priest, put myself in the situation and then decide what will be best ethical decision. I also read a lot of spiritual and religious books and meditate from time to time. I also discuss confusing issues with my peers who help play the role of devil's advocate so I can take the correct decision. All these things helps me sharpen my ethical mindset. E35

\section{- Environment}

There is a long lineage of scholarship that examines the role played by the environment in shaping an ethical mindset. Individuals appear to develop a sense of ethics from their surroundings; this process includes influences from the workplace, superiors, society, friends, family members and the media (Beeri et al., 2013; Parboteeah et al., 2007; Patel and Schaefer, 2009). Similarly, in our sample of Indian executives, a number of areas in the environment were cited as catalysts for fostering an ethical mindset. One commonly mentioned catalyst was educational institutions (by extension, this includes corporate training and development), where a sense of ethics is developed. For example,

A person learns to be ethical when they have more exposure to various environments. This could be personal, professional, media, social, societal, governmental and that exposes him [sic] to the perspective that what is ethical and how we can be ethical. E12

I think childhood, education at schools and university is vital. Ethics should be included in school and university curriculum. E36

Another area in the environment that can potentially influence one's ethical mindset is religious institutions. The interface between the work environment and religiosity has important ramifications for an individual's ethical mindset; further complicating these dynamics is the organizational context within which that person operates (Weaver and Agle, 2002). In other words, there is sometimes tension between one's religious identity and the organizational environment. In some cases, individuals may rely on their personal and organizational goals, and in other cases, their religious identity becomes their modus operandi. An important consideration is finding ways to align those competing factors.

See one is that ethics are inborn and the other is to adopt best practices. As Lord Krishna says every individual is very honest and sincere. It is circumstances which leads him to this. So if we have the right environment people will fall in line and not resort to any of these unethical practices. E10

I think religious values when practiced can transcend into ethical mindset. I practice Islam and its basic tenets of humility, peace, fairness, hardwork and sacrifice, protect the weak and I surrender to God as per what the Quran teaches. I bring these tenets to my workplace - I do not force it onto others in the name of religion. But these values have helped me shape my mindset. E31

- Molding and education 
Although educational institutions are considered to be part of the environment, numerous executives mentioned how education molds an individual's ethical mindset. This finding is in line with a number of extant studies (e.g., Arjoon, 2000; Chakraborty, 1997; Crossan et al., 2013; Hartman, 1998). The interviewees were hopeful that becoming ethical is possible through learning, and they proposed a variety of means, for example, through the use of case examples, reflections, mentoring/grooming, training and development and workshops on ethical behavior. Several executives elucidated:

You have to have an ethical mindset. This can be developed with case study. E2

It takes long time to develop or change ones ethical mindset. If someone is not ethical, it is difficult that they will change. Maybe they need counseling and training. E36

Any business can develop ethical mindset in the same way by training, grooming etc. In our organization we groom our people to be like that. E7

(Company name) has got workshops which we attend regularly and we read lot of books and journals. We come across a lot of practice related issues and what all things are happening in the world. That's how we try to update ourselves and try to have a positive mindset towards ethical practices. E29

- Commitment and leadership

The research focus on ethical leadership uncovered the importance of leadership commitment and leaders' personal involvement in shaping the ethical climate of their organizations (Beeri et al., 2013; Schwartz, 2013; Treviño et al., 2006). Apart from having a zero tolerance policy, the interviewed executives also recognized that building an ethical work climate took time. Furthermore, continuous commitment to the process and setting a good personal example are necessary to ensuring its success. However, one person recognized the importance of allowing employees the space to learn and that the learning process included help in correcting mistakes through counseling or advising. Sometimes, it may be necessary to terminate someone because progress is not made after that individual has been counseled. As illustrated by a few executives,

If you make him [sic] to achieve by using right principles, he [sic] should be taught actually. People who do not have knowledge of these things must be given knowledge. Once they are allowed to practice, once they are given the knowledge, if they are still failing, then the counseling takes over. Even after counseling, if they still fail, then they should be told that they cannot continue as an employee in the ethical System. E1

There is a great degree of understanding and awareness. And there has to be ethical education, there could be internal forums or there should be ethical workshops on that, so that is the part of the ethical leadership team within the organization. E13 
A business mindset is the collection of the top decision makers mindset. So a multinational can have ethical mindset if all the top leaders who take decisions have clean souls and ethical minds. If there is one rotten apple, that person needs to be removed before it starts rotting the rest of them. E36

\title{
Ethical decision making (EDM)
}

Most of our interviewees appeared to be cognizant of EDM and the gravity of their positions as leaders in shaping the ethical climate within their respective organizations. The leadership role emerged as an important theme in EDM in that the executives noted the vicarious learning that can happen in organizations. Simply put, actions speak louder than words, and employees will quickly learn what is acceptable and unacceptable based on their leaders' actions. As such, vicarious learning is consistent with virtue ethics theory, which states that virtues are transmitted through learning and regular practice, until eventually they become good habits (Arjoon, 2000; Audi, 2012; Schaubroeck et al., 2012; Treviño et al., 2006). Conversely, vices are to be avoided. For example, when faced with the dilemma of whether to access information ethically or unethically, key decision makers should resist the temptation to access critical information unethically even if it would benefit them and the organization. The following quotations illustrate the dynamics between virtues, EDM and vicarious learning processes:

Training as a leader because you are a leader, you need to set an example to your employees; set an example that means your moral values as such everything comes in the picture but training helps. E1

We have paid royalties for getting information but we will never get information using any of the unethical practices mentioned above. We have got a technical collaboration with Alstom for nuclear norms. With Siemens we had it done for some motors. We have not gone beyond the dotted lines within these as well. E5

\begin{abstract}
Multinationals need the right mindset to be ethical. It is not about having a clean image but then being dirty inside but about being clean inside and outside. This needs total mindset revamp from the top. Tata is a good example of a multinational that has always had a squeaky clean image based on its founder Jamshedji Tata's values. He was also a Parsi. His sons and grandsons have made sure that the image and legacy continues. I can say that we idolize Tata group and have a mindset because of strong and clean leadership. E34
\end{abstract}

In order to foster EDM, consistency in the application of ethics becomes crucial for leaders. While consistency sends the message that there are certain ethical principles that are not open to negotiation, inconsistency sends the mixed message that in some circumstances or conditions, an individual could be persuaded to decide differently. As one of our executives explained, "Ethical principles cannot be two. It has to be one set of principle" (E26). For MNCs, consistent EDM can be challenging at times because of differences in how various cultures view certain issues or how they prioritize those issues. Consequently, executives sometimes must address an ethical tug-of-war. For example, one person explained the difficulties faced when trying to apply the same ethical standards in Germany, Italy and India. Differences in ethical practices around the world pose tremendous challenges to a universalistic approach to ethics, a problem illustrated in the following examples: 
We have two plants one is in Germany and the other in Italy. We are trying to apply the same values abroad but there is a bit of difference between the Indian and the abroad locations. Confidentiality, transparency, integrity and other values are almost same but there is a bit of difference due to the different culture and attachment to the business. They are too professional but whereas in our case it is not like that. E6

We are exporting 58\% of our sales. All the sales go to all multinational in the world, in different parts of the world and we have to have same practices irrespective of the location. When we apply these qualities outside India, they work very well. When we apply this in India, we are not very successful. E10

An interesting and unexpected finding from the interviews is the role played by emotional intelligence in EDM. One interviewee mentioned the need to manage one's emotions, be self-aware and be critical of the presented choices in order to be an ethical decision maker. According to Culham (2013) and Fu (2014), the relationship between emotional intelligence and ethics is consistent with the notion of virtue ethics, where individuals see themselves as being part of a community, so that their feelings, thoughts and actions have public consequences. As one executive puts it,

So you need to control your emotions. You need to have a check on what you want and how badly you need it and what is the importance of that thing in your life and all these things. You need to put few rhetorical questions for yourself and then only you can get an answer for it and then you decide whether unethical things are better for your life or ethical things. E24

Executives need to have the right balance between what is right and what is wrong. And a clear conscience that can help achieve this. They also need such a mindset to take right ethical decisions. E32

\section{Discussion}

The complex interfaces between religiosity, ethical virtues and ethical mindsets in the context of India's rich cultural, historical and religious heritages provide a fascinating opportunity to study how Indian executives make decisions. On the one hand, there are criticisms of the level of cronyism, nepotism and other forms of favoritism directed at Indian-run organizations (Kohls and Buller, 1994; Quah, 1999). These practices give the impression that unethical practices are widespread in India, as suggested by Transparency International. On the other hand, unethical practices contradict Hindu, Jain, Sikh, Islamic, Buddhist and Christian (all major religions in India) teachings. This paradoxical observation suggests the need to further understand the forces influencing Indian executives' decision-making processes. Furthermore, most extant studies on virtue ethics remain theoretical and normative in nature. Thus, we embarked on this research journey to better understand these interfaces by posing two research questions: (1) Does religiosity influence the ethical virtues and mindsets of Indian executives, and if it does, how? and (2) Do ethical virtues and ethical mindsets influence EDM among Indian executives, and if they do, how?

Virtue ethics theory is a suitable approach to illustrating the dynamics in our study. Because virtue ethics addresses the moral character of a person and the types of character traits that should be inculcated, it is believed to offer better insights into the virtues, mindsets and 
decision-making processes of individuals (Audi, 2012). According to virtue ethics, desirable character traits can be developed through conscious attempts to strive for those virtues and through regular practice. Over time, through regular practice, 'good' habits are thought to develop and become ingrained in a person. A common assumption made in the study of virtue ethics is the transposition of what one considers to be virtuous across different cultures, as if these virtues are valued, prioritized or even expressed in the same way (Issa and Pick, 2010; Shanahan and Hyman, 2003). Thus, empirical studies that are descriptive, rather than prescriptive and ethnocentric, in nature will better serve the purpose of advancing the extant knowledge of how specific cultures or societies value particular virtues. Consequently, in our study, we have sought to answer our research questions by understanding the discourse of our study participants.

Several themes relevant to ethical virtues emerged from the interviews with 40 Indian executives conducted for this study. For example, various executives in our study mentioned taking care of their employees and attending to the needs of their stakeholders in different ways. One executive mentioned being cognizant of where one's authority starts and ends so that employees are not asked to do something unethical. Another discussed treating employees like family members to the extent of helping them to build a home or providing some assistance for the wedding of an employee's daughter. In yet another case, the organization absorbed some of the cost for a systems implementation at a supplier. These examples suggest elements underlying those decisions such as care for employees, consideration of individuals' welfare and a willingness to help individuals within and outside of the organization, which imply the virtues of 'empathy', 'sympathy' and 'humanity'. Next, the executives mentioned taking into consideration the cost and standard of living when they allocated resources. Also, they seemed cognizant of needing to ensure that people were treated fairly by avoiding favoritism. Consistency was an important aspect in their dealings with others, to ensure that the virtues of 'justice' and 'fairness' were upheld. In terms of 'temperance' and 'integrity', it was important for the executives to know where the ethical boundaries were, and at the same time, rules and regulations need to be a component of ethical corporate governance to provide guidance to an organization's stakeholders. Leadership plays a central role in 'governance' and in ensuring that there is 'transparency'. As such, priority should be placed on the recruitment and selection of ethical leaders who will promulgate ethical standards in an organization. A few executives appeared to be adamant about not lying to or cheating their customers. Such 'conscientiousness' is believed to be linked to their transcendental beliefs regardless of their religious backgrounds. 'Wisdom' was another important ethical virtue that helped to guide the executives to prudently address ethical dilemmas and to take corrective action. Yet, this wisdom needs to be accompanied by the moral fortitude and determination to implement and to follow-up on ethical principles and practices. Otherwise, this wisdom remains at the level of knowledge about what to do rather than practical ethics. The interviewed executives believed that the regular practices of 'wisdom', 'moral fortitude' and 'determination' help them to cope with ethical challenges and avoid an ethical slip up, which suggests the practice of virtue ethics. These findings provided some insights into the ethical virtues that are considered important among the interviewed Indian executives and demonstrated some variance from those reported in extant studies (cf. Donlevy and Walker, 2011; Patel and Schaefer, 2009; Resick et al., 2006).

Although the notions of ethical virtues and ethical mindsets have been used interchangeably, the former refers to a set of deep-seated ideals and the latter refers to a set of attitudes or dispositions. It is our contention that an ethical mindset is the product of and attempt at realizing ethical virtues. In our study, an ethical mindset appears to be composed of the 
following several themes. For a workplace to be ethical, senior executives need to create an organizational 'environment' in which ethics can thrive. Several of the tested methods for creating an ethical culture include relying on ethically based policies, ensuring that everyone in the organization understands the policies, communicating expectations, reprimanding someone who breaches ethical standards, encouraging everyone to use introspection on a daily basis, and setting a good example for others to follow. Because individuals learn from their environment vicariously, it is extremely important to ensure that appropriate molding and education are provided, such as setting a good example of ethical behavior, and that appropriate training and development in the area of ethics are provided (Arjoon, 2000). Grooming or mentorship is another way to facilitate a positive vicarious learning opportunity (Brown and Treviño, 2013). In any case, individuals should be given adequate space and time to learn (Fyke and Buzzanell, 2013). Termination should be reserved for a major ethical breach or when someone has failed to demonstrate any improvement after training, development, counseling, grooming or mentoring. Finally, the organizational leaders should commit to ethical initiatives through their personal actions, interactions with others, and involvement in ethical programs as well as by holding themselves and others accountable (Brown and Mitchell, 2010; Brown and Treviño, 2013). Thus, for the purpose of our study, an ethical mindset is a set of processes that aim at bringing ethics to the consciousness of individuals. As in the case of ethical virtues, an ethical mindset might vary across organizations, cultures and societies.

Religiosity plays a salient role in shaping the ethical virtues and mindsets of the executives. Subscription to a particular religion compels an individual to adopt certain virtues and beliefs as part of their 'road map', and this can potentially affect decision making (Melé, 2015; Taghavi, 2013). While the executives in our study came from a variety of religious traditions (e.g., Hinduism, Sikhism, Jainism, Islam, Christianity and Zoroastrianism), they reported positive influences from religiosity in their work lives. Generally speaking, religiosity is a discipline that requires regular practice and commitment and when acceptable and unacceptable thoughts, speeches and behaviors are part of the teachings, ethics can be reinforced in an individual. Thus, the principles of virtue ethics are relevant and applicable in this case. Whether being ethical is about improving one's Karma or ending up in a better place after this life, religiosity has a profound impact at the level of one's consciousness (or even unconsciousness) and at the level of decision making. However, our findings do not suggest that someone who is religious would not succumb to unethical behaviors, as there are countless examples of ethical shortcomings as a result of human weakness committed by those considered to be religious.

Taken together, religiosity, ethical virtues and ethical mindsets have the potential to influence decision making. One unanimous theme among the executives' comments was that leadership played a vital role in ensuring that decisions at various organizational levels will be ethical. The cascading effect of ethical leadership is most likely due to vicarious learning. Thus, consistency in EDM is necessary to ensure that ethics are reinforced. Conversely, a schizophrenic decision-making style with a high regard for ethics one day and disregard the next only conveys that compromises are acceptable. However, some executives did point out that ethical standards and expectations might vary across countries, which makes EDM difficult at times. This conundrum may explain why certain well-intentioned individuals cave in, but those who remain consistent in their ethical virtues and mindsets (reinforced by their religiosity) choose not to engage in unethical decisions. Furthermore, one executive suggested that emotional intelligence could be another resource to draw from when faced with an ethical dilemma. Emotional intelligence appears to provide the clarity needed to 
discern whether the decision is ethical or not, and it is a skill that is sorely needed for leadership development.

\section{Theoretical and practical contributions}

This study makes several theoretical contributions. We drew on virtue ethics theory and demonstrated how religiosity could influence the ethical virtues, mindsets and EDM of executives in a multi-faith Indian society. Furthermore, this study adds to the extant anecdotal and empirical evidence (e.g., Chakraborty, 1997; Mulla and Krishnan, 2014) on ethics in India by revealing the prevalent ethical virtues that are germane to this group of Indian executives. Religiosity appears to play an important role in these executives' EDM. Last, the EDM framework developed in this study could be tested in other contexts, particularly with multi-faith populations.

Several practical implications can be drawn from this study. Several important ethical virtues featured prominently in our study. For example, how leaders treat others signals the virtues that they wish to inculcate in their organizations. In our study, these leaders thought that EDM could be encouraged by demonstrating empathy, sympathy, humanity, treating others justly and fairly, practicing temperance, high personal integrity, transparency, good governance, being conscientious about ethical issues, seeking transcendence, harnessing the wisdom to discern properly and having the moral fortitude and determination to stand up against unethical practices. A commonality among these virtues is their relational aspect, and they are they have been identified as the virtues espoused by the executives. One implication, then, is for these executives to instill those virtues in the organization and for the internal stakeholders to internalize them. An ethical mindset composed of an ethical culture and environment, through the molding and education of all employees, could then be developed through the relentless commitment of leadership. Thus, leadership underpins the ethical tone of organizations in numerous ways. There is a need for leaders who are committed in both words and deeds to the ethical initiatives of their organizations. Related to this need is the selection or appointment of appropriate leaders who will hold themselves and others to account. Similarly, "buy-in" is important, in that these ethical virtues should be shared by everyone in order for EDM to occur.

\section{Limitations and suggestions for future research}

Our study acknowledges several limitations. Our study is based on interviews with 40 executives from 40 multinational firms in India. Due care was taken to ensure that our sample was representative of the religious demography in India based on the census data; it is difficult to ascertain, however, whether these views reflect those of the general population in a country with an society steeped in religiosity. Moreover, our findings are based on interviews with only one member of each top management team for the 40 firms, and strategic decision making, including that focused on ethics, might be the prerogative of top management teams wherein each individual's religious preference would impact EDM at the organizational level. In this context, future studies are encouraged to focus on how top management teams arrive at ethical decisions. Similarly, if indeed ethical virtues and mindsets are religion based, then the extent to which others, especially managers and employees, internalize those virtues and share those mindsets needs to be understood. Thus, future studies should consider comparing the responses provided by leaders and followers with regard to ethical virtues, mindsets and EDM. 
The ethical virtues and mindsets in our study may be context driven, and future studies involving other religious traditions might discover similar andor different virtues and mindsets. Also, our study does not explain why apparently religious individuals sometimes resort to unethical practices, and this paradox warrants further exploration. Furthermore, it is important to conduct studies that compare Indian nationals and descendants in other national contexts. Such a cross-national inquiry may unveil the different critical institutional forces that influence how executives make decisions. Also, a mixed method approach that includes a quantitative study would enrich our understanding of faith, ethics and decision making. For instance, it may be the case that only certain virtues and mindsets are related to religiosity and that only certain virtues and mindsets are important determinants of EDM.

Socio-political forces should also be considered, as they could determine the relative ease or difficulty in introducing religious-based ethics. For example, in a country where there is relative freedom of faith, this could be less of a challenge in comparison to a theocratic nation. The incorporation of faith-based virtues, principles and practices may also be hampered or limited by the presence of human rights legislation and anti-discrimination laws, such that similar to the concept of 'separation of church and state', there is a 'separation of faith and organizations' in the interest of protecting everyone from any unnecessary harassment. In a similar vein, it would be informative to explore how certain religious-based ethical virtues are upheld in various contexts, such as in a country where there is no official religion, but a majority of the population belongs to a certain faith.

Finally, although great care had been taken to minimize social desirability bias, there is no guarantee that it was never present. Given that the respondents were candid in discussing unethical practices, there is some assurance that the steps undertaken were successful. Future studies could incorporate a triangulated design whereby the responses provided by one group of respondents are verified with those provided by another group within the same organization.

\section{Conclusion}

Despite growing interest in the interfaces between religiosity and EDM in the past few decades, little is currently known about how religious-based ethics are incorporated into organizations. Much of what has been written about ethics in India is based on anecdotal and empirical evidence that presumes that a certain set of ethical virtues and mindsets exist. However, it does not explain which virtues and mindsets are esteemed or favored in the context of Indian MNCs. Through the use of a qualitative methodology, we were able to discern whether these executives' EDM was influenced by their religiosity, ethical virtues and ethical mindsets. Furthermore, we were able to determine which components of the ethical virtues and mindsets contributed to EDM. Future researchers are encouraged to empirically assess and extend the EDM framework presented in this paper to other multi-faith populations.

\section{References}

Adeel, M.A. (2015). Moderation in Greek and Islamic traditions, and a virtue ethics of the Qur'an. American Journal of Islamic Social Sciences, 32(3), 1-28. 
Ali, A.J. and Al-Aali, A. (2015). Marketing and ethics: What Islamic ethics have contributed and the challenges ahead. Journal of Business Ethics, 129(4), 833-845.

Ali, A.J., Al-Aali, A. and Al-Owaihan, A. (2013). Islamic perspectives on profit maximization. Journal of Business Ethics, 117(3), 467-475.

Ananthram, S. and Chan, C.C.A (in press). Religiosity, spirituality and ethical decisionmaking: Perspectives from executives in Indian multinational enterprises. Asia Pacific Journal of Management,

Ansari, A.H. (1989). Islamic ethics: Concept and prospect. American Journal of Islamic Social Sciences, 6(1), 81-91.

Arjoon, S. (2000). Virtue theory as a dynamic theory of business. Journal of Business Ethics, 28(2), 159-178.

Ashtankar, O.M. (2015). Relevance of Buddhism for business management. International Journal of Applied Research, 1(13), 17-20.

Audi, R. (2012). Virtue ethics as a resource in business. Business Ethics Quarterly, 22(2), 273-291.

Beadle, R. and Moore, G. (2006). MacIntyre on virtue and organization. Organization Studies, 27(3), 323-340.

Beeri, I., Dayan, R., Vigoda-Gadot, E. and Werner, S.B. (2013). Advancing ethics in public organizations: The impact of an ethics program on employees' perceptions and behaviors in a regional council. Journal of Business Ethics, 112(1), 59-78.

Benedict XVI (2006). Deus caritas est. http://w2.vatican.va/content/benedictxvi/en/encyclicals/documents/hf_ben-xvi_enc_20051225_deus-caritas-est.html, Accessed on 7 May, 2016.

Boeije, H. (2010) Analysis in Qualitative Research. London: Sage.

Brown, M.E. and Mitchell, M.S. (2010). Ethical and unethical leadership: Exploring new avenues for future research. Business Ethics Quarterly, 20(4), 583-616.

Brown, M.E. and Treviño, L.K. (2013). Do role models matter?: An investigation of role modeling as an antecedent of perceived ethical leadership. Journal of Business Ethics, 122(4), 587-598.

Brunk, K.H. (2010). Exploring origins of ethical company/brand perceptions - A consumer perspective of corporate ethics. Journal of Business Research, 63(3), 255-262.

Buch, M.A. (1919). Zoroastrian ethics. Baroda: Mission Press.

Buckley, M. (2013). A construcivist approach to business ethics. Journal of Business Ethics, 117(4), 695-706.

Carpenter, M.A., Geletkanycz, M.A., and Sanders, W.G. (2004). Upper echelons research revisited: Antecedents, elements, and consequences of top management team composition. Journal of Management, 30(6), 749-778.

Census of India (2001). Religion. http://censusindia.gov.in/Census_And_You/religion.aspx Accessed on 25 April, 2016).

Chakraborty, S.K. (1997). Business ethics in India. Journal of Business Ethics, 16(14), 15291538 .

Chan-Serafin, S., Brief, A.P. and George, J.M. (2013). How does religion matter and why?: Religion and the organizational sciences. Organization Science, 24(5), 1585-1600.

Chattopadhyay, C. (2012). Indian philosophy and business ethics: A review. Advances in Management \& Applied Economics, 2(3), 111-123.

Chun, R. (2005). Ethical character and virtue of organizations: An empirical assessment and strategic implications. Journal of Business Ethics, 57(3), 269-284.

Conroy, S.J. and Emerson, T.L.N. (2004). Business ethics and religion: Religiosity as a predictor of ethical awareness among students. Journal of Business Studies, 50(4), 383396. 
Cornelissen, G., Bashshur, M.R., Rode, J. and Le Menestrel, M. (2013). Rules or consequences?: The role of ethical mind-sets in moral dynamics. Psychological Science, 24(4), 482-488

Crossan, M., Mazutis, D. and Seijts, G. (2013). In search of virtue: The role of virtues, values and character strengths in ethical decision making. Journal of Business Ethics, 113(4), 567-581.

Culham, T.E. (2013). Ethics education of business leaders: Emotional intelligence, virtues, and contemplative learning. In J. Lin and R. Oxford (Eds.) Book Series: Transforming Education for the Future. Charlotte: Information Age Publishing, pp.15-39.

Dahlsgaard, K., Peterson, C. and Selgman, M.E.P. (2005). Shared virtues: The convergence of valued human strengths across culture and history. Review of General Psychology, 9(3), 203-213.

Davidson, J.C. and Caddell, D.P. (1994). Religion and the meaning of work. Journal for the Scientific Study of Religion, 33(2), 135-147.

Demuijnck, G. (2015). Universal values and virtues in management versus cross-cultural moral relativism: An educational strategy to clear the ground for business ethics. Journal of Business Ethics, 128(4), 817-835.

Deutsch, E. and Dalvi, R. (2004). The Essential Vedanta: A New Source Book of Advaita Vedanta. Bloomington, IN: World Wisdom Inc.

Donlevy, J.K. and Walker, K.D. (2011). Working through ethics in education and leadership: Theory, analysis, plays, cases, poems, prose, and speeches. Rotterdam: Sense Publishers.

Dust, S. and Greenhaus, J. (2013). Spirituality and the work-home interface: A demandsresources perspective. Journal of Management, Spirituality and Religion, 10(3), 282-305.

Eisenbeiss, S.A., van Knippenberg, D. and Fahrbach, C.M. (2015). Relationship between CEO ethical leadership and firm performance. Journal of Business Ethics, 128(3), 635651.

Engelstad, F. (1997). Needs and social justice: The criterion of needs when exempting employees from layoff. Social Justice Research, 10(2), 203-223.

Ernst \& Young (2014). Bribery and corruption: Ground reality in India. http://www.ey.com/Publication/vwLUAssets/Bribery_and_corruption:_ground_reality_in_ India/\$FILE/EY-FIDS-Bribery-andcorruption-ground-reality-in-India.pdf, Accessed on 6 May 2016.

Fernando, A.C. (2009). Business ethics: An Indian perspective. New Delhi: Dorling Kindersley.

Fernando, M. and Jackson, B. (2006). The influence of religion-based workplace spirituality on business leaders' decision-making: An inter-faith study. Journal of Management and Organization, 12(1), 23-39.

Fernando, M. and Moore, G. (2015). MacIntyrean virtue ethics in business: A cross-cultural comparison. Journal of Business Ethics, 132(1), 185-202.

Ferrero, I. and Sison, A.J.G. (2014). A quantitative analysis of authors, schools and themes in virtue ethics articles in business ethics and management journals (1980-2011). Business Ethics: A European Review, 23(4), 375-400.

Fowers, B.J. (2003). Reason and human finitude: In praise of practical wisdom. American Behavioral Scientist, 47(4), 415-426.

Frémeaux, S. and Michelson, G. (2011). 'No strings attached': Welcoming the existential gift in business. Journal of Business Ethics, 99(1), 63-75.

$\mathrm{Fu}, \mathrm{W}$. (2014). The impact of emotional intelligence, organizational commitment, and job satisfaction on ethical behavior of Chinese employees. Journal of Business Ethics, 122(1), 137-144. 
Fyke, J.P. and Buzzanell, P.M. (2013). The ethics of conscious capitalism: Wicked problems in leading change and changing leaders. Human Relations, 66(12), 1619-1643.

Glaser, B.G. and Strauss, A.L. (2012). The Discovery of Grounded Theory: Strategies for Qualitativ Research. Piscataway, NJ: AldineTransaction.

Glover, S.H., Bumpus, M.A., Logan, J.E. and Ciesla, J.R. (1997). Re-examining the influence of individual values on ethical decision making. Journal of Business Ethics, 16(2), 13191329.

Guillén, M., Ferrero, I. and Hoffman, W.M. (2015). The neglected ethical and spiritual motivations in the workplace. Journal of Business Ethics, 128(4), 803-816.

Hannah, S.T., Avolio, B.J. and Walumbwa, F.O. (2011). Relationships between authentic leadership, moral courage, and ethical and pro-social behaviors. Business Ethics Quarterly, 21(4), 555-578.

Hartman, E.M. (1998). The role of character in business ethics. Business Ethics Quarterly, $8(3), 547-559$.

Herring, H.L. (1929). The beginnings of industrial social work. Social Forces, 5(1). 217-324.

Holdrege, B. A. 1991. Hindu ethics. In J. Carman and M. Juergensmeyer (Eds.). A bibliographic guide to the comparative study of ethics. Cambridge: Cambridge University Press.

Issa, T. and Pick, T. (2010). Ethical mindsets: An Australian study. Journal of Business Ethics, 96(4), 613-629.

Iyer, M. (2009). Faith and Philosophy of Zoroastrianism. New Delhi: Kalpaz Publications.

Jaini, P.S. (2004). Ahimsa and "just war" in Jainism. In T. Sethia (Ed), Ahimsa, Anekanta, and Jainism. New Delhi: Motilal Banarsidass Publishers.

Jordan, J., Brown, M.E., Treviño, L.K. and Finkelstein, S. (2013). Someone to look up to executive-follower ethical reasoning and perceptions of ethical leadership. Journal of Management, 39(3), 660-683.

Kalshoven, K., Den Hartog, D.B. and De Hoogh, A.H.B. (2010). Ethical leader behavior and big five factors of personality. Journal of Business Ethics, 100(2), 349-366.

Kangas, M., Feldt, T., Huhtala, M. and Rantanen, J. (2014). The corporate ethical virtues scale: Factorial invariance across organizational samples. Journal of Business Ethics, 124(1), 161-171.

Keaveney, S. (1995). Customer switching behavior in service industries: An exploratory study. Journal of Marketing, 59, 71-82.

Koehn, D. (2013). East meets West: Toward a universal ethic of virtue for global business. Journal of Business Ethics, 116(4), 703-715.

Kohls, J. and Buller, P. (1994). Resolving cross-cultural ethical conflict: Exploring alternative strategies. Journal of Business Ethics, 13(1), 31-38.

Konow, J. (2001). Fair and square: The four sides of distributive justice. Journal of Economic Behavior \& Organization, 46(2), 137-164.

Kriger, M. (2013). Wise leadership in organizations; Integrating Eastern and Western paradigms. In J. Neal (ed.), Handbook of faith and spirituality in the workplace: Emerging research and practice, New York: Springer, pp. 255-269.

Kvale, S. (1996). InterViews: An introduction to qualitative research interviewing. Thousand Oaks, CA: Sage.

Kvale, S. (2007) Doing interviews. Thousand Oaks, CA: Sage.

Lee, M. and Ruhe, J.A. (1999). Ethical mindsets of Christianity and Confucianism: A comparative study. International Journal of Value-Based Management, 12(1), 13-27.

Lindsay, V. (2004). Computer-assisted qualitative data analysis: Application in an export study, in Handbook of Qualitative Research Methods for International Business, eds. R. Marschan-Piekkari and C. Welch, Cheltenham: Edward Elgar, pp. 486-506. 
Lutz, D.W. (2009). African Ubuntu philosophy and global management. Journal of Business Ethics, 84, 313-328.

MacIntyre, A. (1999). Dependent Rational Animals: Why Human Beings Need the Virtues. London: Duckworth.

MacIntyre, A. (2007). After Virtue: A Study of Moral Theory, $3^{\text {rd }}$ edn., Notre Dame, IN: University of Notre Dame Press.

Marques, J .(2009). Toward greater consciousness in the $21^{\text {st }}$ century workplace: How Buddhist practices fit in. Journal of Business Ethics, 92(2), 211-225.

Melé, D. (2015). Religious approaches on business ethics: Current situation and future perspectives. Ramon Llull Journal of Applied Ethics, 6, 137-160.

Menon, R. (2004). The Ramayana: A modern retelling of the great Indian epic. New York: North Point Press.

Mensah, Y.M. (2014). An analysis of the effect of culture and religion on perceived corruption in a global context. Journal of Business Ethics, 121(2), 255-282.

Miles, M.B. and Huberman, A.M. (1994). Qualitative data analysis: An expanded sourcebook. 2nd ed. Thousand Oaks, CA: Sage.

Miller, D.W. and Ewest, T. (2013). Rethinking the impact of religion on business values: Understanding its re-emergence and measuring its manifestations. In S. Rothlin and P. Haghirian (eds), Dimensions of Teaching Business Ethics in Asia, New York: Springer.

Moberg, D.J. (1999). The big five and organizational virtue. Business Ethics Quarterly, 9(2), 245-272.

Moore, G. (2005). Corporate character: Modern virtue ethics and the virtuous corporation. Business Ethics Quarterly, 15(4), 659-685.

Morales-Sànchez, R. and Cabello-Medina, C. (2013). The role of four universal moral competencies in ethical decision-making. Journal of Business Ethics, 116(4), 717-734.

Mulla, Z.R. and Krishnan, V.R. (2014). Karma-Yoga: The Indian model of moral development. Journal of Business Ethics, 123 (2), 339-351.

Muniapan, B. (2015). The Bhagavad-Gita and business ethics: A leadership perspective. In D.K. Ura and P.O. de Pablos (Eds), Asian Business and Management Practices: Trends and Global Considerations, Hershey, PA: Business Science Reference, pp.232-253.

Murphy, P.E. (1999). Character and virtue ethics in international marketing: An agenda for managers, researchers and educators. Journal of Business Ethics, 18(1), 107-124.

Narasimhan, N., Bhaskar, K. and Prakhya, S. (2010). Existential beliefs and values. Journal of Business Ethics, 96(3), 369-382.

Nederhof, A.J. (1985). Methods of coping with social desirability bias: A review. European Journal of Social Psychology, 15, 263-280.

Nielsen, B. and Nielsen, S. (2011). The role of top management team international orientation in international strategic decision-making: the choice of foreign entry mode. Journal of World Business, 46(2), 185-193.

Pandey, A., Gupta, R.K. and Arora, A.P. (2009). Spiritual climate of business organizations and its impact on customers' experience. Journal of Business Ethics, 88(2), 313-332.

Paramananda, S. (1919). The Upanishads, $2^{\text {nd }}$ edn., Boston, MA: The Vedanta Center.

Parboteeach, K.P., Hoegl, M. and Cullen, J.B. (2007). Ethics and religion: An empirical test of a multidimensional model. Journal of Business Ethics, 80(2), 387-398.

Patel, T. and Schaefer, A. (2009). Making sense of the diversity of ethical decision making in business: An illustration of the Indian context. Journal of Business Ethics, 90(2), 171-186.

Pinto, J., Leana, C.R. and Pil, F.K. (2008). Corrupt organizations or organizations of corrupt individuals? Two types of organization-level corruption. Academy of Management Review, 33(3), 685-709. 
Quah, J.S.T. (1999). Corruption in Asian countries: Can it be minimized?. Public Administration Review, 59(6), 483-494.

Resick, C.J., Hanges, P.J., Dickson, M.W. and Mitchelson, J.K. (2006). A cross-cultural examination of the endorsement of ethical leadership. Journal of Business Ethics, 63(4), 345-359.

Robertson, C. and Fadil, P.A. (1999). Ethical decision making in multinational organizations: A culture-based model. Journal of Business Ethics, 19(4), 385-392.

Rodgers, W. and Gago, S. (2006). Biblical scriptures underlying six ethical models influencing organizational practices. Journal of Business Ethics, 64(2), 125-136.

Rose, J. (2011). Zoroastrianism: A guide for the perplexed. New York: Continuum International Publishing Group.

Schaubroeck, J.M., Hannah, S.T., Avolio, B.J., Kozlowski, S.W., Lord, R.G., Treviño, L.K., Dimotakis, N., and Peng, A.C. (2012). Embedding ethical leadership within and across organizational levels. Academy of Management Journal, 55, 1053-1078.

Sekerka, L.E. and Bagozzi, R.P. (2007). Moral courage in the workplace: Moving to and from the desire and decision to act. Business Ethics Quarterly, 16(2), 132-149.

Shanahan, K.J. and Hyman, M.R. (2003). The development of a virtue ethics scale. Journal of Business Ethics, 42(2), 197-208.

Sidani, Y. and Al Ariss, A. (2015). New conceptual foundations for Islamic business ethics: The contributions of Abu-Hamid Al-Ghazali. Journal of Business Ethics, 129, 847-857.

Silverman, D. (2000). Doing Qualitative Research: A Practical Handbook. London: Sage.

Singh, A.K. (2000). The universal ideal of Sikhism. Global Dialogue, 2(1), 99-108.

Singh, C. (2013). Ethics and business: Evidence from the Sikh religion. Working Paper No. 439, Bangalore: Indian Institute of Management.

Singh, J. (2005). Ethics of the Sikhs. Understanding Sikhism - The Research Journal, 7(1), 35-38.

Sinkovics, R.R., Elfriede, P., and Ghauri, P.N. (2008). Enhancing the trustworthiness of qualitative research in international business. Management International Review, 48(6), 689-714.

Sison, A.J.G. and Fontrodona, J. (2013). Participating in the common good of the firm. Journal of Business Ethics, 113(4), 611-625.

Srinivasan, V. (2011). Business ethics in the south and South East Asia. Journal of Business Ethics, 104, 73-81.

Storsletten, V.M.L. and Jakobsen, O.D. (2015). Development of leadership theory in the perspective of Kierkegaard's philosophy. Journal of Business Ethics, 128(2), 337-349.

Sternberg, R.J. (2004). Words to the wise about wisdom?: A commentary on Ardelt's critique of Baltes. Human Development, 47, 286-289.

Strauss, A. and Corbin, J. (1997). Basics of Qualitative Research: Grounded Theory Procedures and Techniques, $3^{\text {rd }}$ edn., Thousand Oaks, CA: Sage.

Schwartz, M.S. (2013). Developing and sustaining an ethical corporate culture: The core elements. Business Horizons, 56(1), 39-50.

Taghavi, S. (2013). How mindset mediates the impact of spirituality on work attitude: A conceptual model. Academy of Management Conference, August, Orlando: FL.

Tanquerey, A. (1930). The Spiritual Life: A Treatise on Ascetical and Mystical Theology, $2^{\text {nd }}$ and revised edition, Tournai: Society of St. John the Evangelist, Desolée \& Co. (Translated by Reverend Herman Branderis).

Tater, S.R. (2010). Enlightened Knowledge. New Delhi: Readworthy Publications Ltd. (Edited by Harihar Sharma).

The New American Bible, Revised Edition (2011). http://www.usccb.org/bible/books-of-thebible/index.cfm, Accessed on 7 May, 2016. 
Transparency International (2015). https://www.transparency.org/country/\#IND, Accessed on 17 May, 2016)

Treviño, L.K., Weaver, G.R. and Reynolds, S.J. (2006). Behavioral ethics in organizations: A review. Journal of Management, 32(6), 951-990.

Van Buren III, H.J. and Greenwood, M. (2013). The genesis of employment ethics. Journal of Business Ethics, 117(4), 707-719.

van Nooten, B.A. (2000). Introduction. In W. Buck, Ramayana. Berkeley, CA: University of California Press.

Verdorfer, A.P., Steinheider, B. and Burkus, D. (2015). Exploring the socio-moral climate in organizations: An empirical examination of determinant, consequences, and mediating mechanism. Journal of Business Ethics, 132(1), 233-248.

von Glasenapp, H. (1999). Jainism: An Indian Religion of Salvation. New Delhi: Motilal Banarsidass Publishers.

Wade, R. (2010). Bridging Christianity, Islam, and Buddhism with virtue ethics. In K. Engebretson, M. de Souza, G. Durka and L. Gearson (Eds). International Handbook of Inter-Religious Education. New York, NY: Springer.

Wang, G. and Hackett, R.D. (in press). Conceptualization and measurement of virtuous leadership: Doing well by doing good. Journal of Business Ethics,

Weaver, G.R. and Agle, B.R. (2002). Religiosity and ethical behavior in organizations: A symbolic interactionist perspective. Academy of Management Review, 27(1), 77-97.

Worden, S. (2003). The role of religious and nationalistic ethics in strategic leadership: The case of J. N. Tata. Journal of Business Ethics, 47(2), 147-164.

Yusof, M., Nor, L.M. and Hoopes, J.E. (2014). Virtuous CSR: An Islamic family business in Malaysia. Journal of Family Business Management, 4(2), 133-148.

Zaroug, A.H. (1999). Ethics from an Islamic perspective: Basic issues. Journal of Islamic Social

Sciences, $16(3)$,

45-63. 
Table 1: Summary of participants' background

\begin{tabular}{|c|c|c|c|c|c|c|c|c|c|c|c|}
\hline $\begin{array}{l}\mathrm{Sr} \\
\text { No }\end{array}$ & Position & Industry & Gender & Age & $\begin{array}{l}\text { Position } \\
\text { Tenure }\end{array}$ & $\begin{array}{l}\text { Industry } \\
\text { Tenure }\end{array}$ & Education & $\begin{array}{l}\text { Overseas } \\
\text { Education }\end{array}$ & Work Overseas & $\begin{array}{l}\text { Overseas } \\
\text { Tenure }\end{array}$ & Religion \\
\hline E1. & $\begin{array}{l}\text { Director of Finance } \\
\text { and Company } \\
\text { Secretary }\end{array}$ & $\begin{array}{l}\text { Information } \\
\text { Technology }\end{array}$ & Male & $51-55$ & 12 & 27 & Doctorate & USA & $\begin{array}{l}\text { Dubai, Singapore, } \\
\text { Sri Lanka, Egypt, } \\
\text { Oman and Thailand }\end{array}$ & 7 years & Hindu \\
\hline E2. & $\begin{array}{l}\text { Chairman and } \\
\text { Managing Director }\end{array}$ & Pharmaceuticals & Male & $>60$ & 30 & 34 & Masters & - & Ukraine & 1.5 years & Jain \\
\hline E3. & Technical advisor & Automotive & Male & $>60$ & 8 & 41 & Bachelors & $\begin{array}{l}\text { Diploma } \\
\text { courses } \\
\text { from UK, } \\
\text { Germany, } \\
\text { USA }\end{array}$ & $\begin{array}{l}\text { UK, Germany, USA } \\
\text { and Japan }\end{array}$ & Short trips & Hindu \\
\hline E4. & $\begin{array}{l}\text { Assistant General } \\
\text { Manager }\end{array}$ & Renewable Industry & Male & $31-35$ & 10 & 12 & Masters & Australia & $\begin{array}{l}\text { Australia and } \\
\text { Denmark }\end{array}$ & $\begin{array}{l}8 \text { months }- \\
2.5 \text { years }\end{array}$ & Hindu \\
\hline E5. & $\begin{array}{l}\text { Additional General } \\
\text { Manager (Heading } \\
\text { Gujarat) }\end{array}$ & Heavy Engineering & Female & $51-55$ & 15 & 28 & Masters & - & - & - & Hindu \\
\hline E6. & Manager - TPM & $\begin{array}{l}\text { Automobile } \\
\text { Industry }\end{array}$ & Male & $31-35$ & 3 & 10 & Masters & - & Italy & 1.5 years & Hindu \\
\hline E7. & Vice President & $\begin{array}{l}\text { Shipping and } \\
\text { Logistics }\end{array}$ & Female & $46-50$ & 10 & 28 & Masters & Sweden & - & - & - \\
\hline E8. & $\begin{array}{l}\text { Founder, Managing } \\
\text { Director and Chief } \\
\text { Executive Officer }\end{array}$ & $\begin{array}{l}\text { Information } \\
\text { Technology }\end{array}$ & Female & $46-50$ & 12 & 27 & Masters & - & - & - & Hindu \\
\hline E9. & Managing Director & $\begin{array}{l}\text { Information } \\
\text { Technology }\end{array}$ & Male & $36-40$ & 15 & 15 & Bachelors & - & - & - & Hindu \\
\hline E10. & $\begin{array}{l}\text { Chairman and } \\
\text { Managing Director }\end{array}$ & Engineering & Male & $51-55$ & 3 & 25 & Masters & USA & - & - & Hindu \\
\hline
\end{tabular}




\begin{tabular}{|c|c|c|c|c|c|c|c|c|c|c|c|}
\hline E11. & $\begin{array}{l}\text { Head IT } \\
\text { Infrastructure }\end{array}$ & Manufacturing & Male & $31-35$ & 5 & 14 & Masters & - & Italy & 1 month & Hindu \\
\hline E12. & Head of Sales & Telecom & Male & $41-45$ & 1 & 9 & Masters & - & Dubai and Bahrain & 4 years & Hindu \\
\hline E13. & Global IT Head & Pharmaceuticals & Male & $41-45$ & 6 & 18 & Masters & - & $\begin{array}{l}\text { US, UK and } \\
\text { Malaysia }\end{array}$ & 7 months & Hindu \\
\hline E14. & $\begin{array}{l}\text { Founder and } \\
\text { Managing Director }\end{array}$ & Travel and Tourism & Female & $36-40$ & 3 & 4 & Bachelors & - & $\begin{array}{l}\text { Hong Kong, Dubai, } \\
\text { Sri Lanka, Turkey }\end{array}$ & $\begin{array}{l}\text { Short business } \\
\text { trips }\end{array}$ & Sikh \\
\hline E15. & Senior Manager HR & Healthcare & Female & $31-35$ & $<1$ & 12 & Masters & - & - & - & Hindu \\
\hline E16. & $\begin{array}{l}\text { Head Corporate } \\
\text { Affairs }\end{array}$ & $\begin{array}{l}\text { Information } \\
\text { Technology }\end{array}$ & Female & $46-50$ & 1.5 & $4-5$ & Masters & - & - & - & - \\
\hline E17. & $\begin{array}{l}\text { Senior Project } \\
\text { Manager of } \\
\text { Business } \\
\text { Intelligence and } \\
\text { Analytics }\end{array}$ & $\begin{array}{l}\text { Information } \\
\text { Technology }\end{array}$ & Female & $36-40$ & 4 & 10 & Masters & - & $\begin{array}{l}\text { UK and Northern } \\
\text { Ireland }\end{array}$ & $\begin{array}{l}2 \text { or } 3 \text { weeks } \\
\text { for business } \\
\text { tour }\end{array}$ & Hindu \\
\hline E18. & Chief of Laboratory & Healthcare & Female & $36-40$ & 3 & 11 & Doctorate & - & - & - & Hindu \\
\hline E19. & $\begin{array}{l}\text { General Manager } \\
\text { Information } \\
\text { Technology }\end{array}$ & Infrastructure & Male & $41-45$ & 1 & 1 & Masters & - & - & - & Jain \\
\hline E20. & $\begin{array}{l}\text { Chief Information } \\
\text { Officer }\end{array}$ & $\begin{array}{l}\text { Information } \\
\text { Technology }\end{array}$ & Male & $>60$ & $<1$ & 40 & Masters & - & - & - & Hindu \\
\hline E21. & $\begin{array}{l}\text { Chief Executive } \\
\text { Officer }\end{array}$ & Tyre Manufacturing & Male & $46-50$ & 18 & 18 & Bachelors & - & Dubai & 8 years & Hindu \\
\hline E22. & Founder Member & Chip Designing & Male & $>60$ & 18 & 40 & Bachelors & - & $\begin{array}{l}\text { Entire Europe, } \\
\text { USA, Nordic } \\
\text { countries }\end{array}$ & $\begin{array}{l}\text { Short business } \\
\text { trips }\end{array}$ & Hindu \\
\hline E23. & $\begin{array}{l}\text { Deputy General } \\
\text { Manager }\end{array}$ & $\begin{array}{l}\text { Cement } \\
\text { Manufacturing }\end{array}$ & Male & $41-45$ & 15 & 7 & Masters & - & $\begin{array}{l}\text { Saudi Arabia, } \\
\text { Egypt, } \\
\text { Mozambique, } \\
\text { Kenya, Ethiopia, } \\
\text { Djibouti, Indonesia. }\end{array}$ & $\begin{array}{l}\text { Project based } \\
\text { trips }\end{array}$ & Hindu \\
\hline
\end{tabular}




\begin{tabular}{|c|c|c|c|c|c|c|c|c|c|c|c|}
\hline E24. & $\begin{array}{l}\text { National Business } \\
\text { Head }\end{array}$ & $\begin{array}{l}\text { Information } \\
\text { Technology }\end{array}$ & Female & $31-35$ & 8 & 12 & Masters & - & - & - & Hindu \\
\hline E25. & $\begin{array}{l}\text { Head of } \\
\text { Recruitments and } \\
\text { Assessments }\end{array}$ & Education & Female & $41-45$ & 2 & 2 & Masters & - & - & - & Hindu \\
\hline E26. & $\begin{array}{l}\text { Chief Financial } \\
\text { Officer }\end{array}$ & $\begin{array}{l}\text { Fast Moving } \\
\text { Consumer Goods }\end{array}$ & Male & $51-55$ & 3.5 & 8 & Masters & - & USA and Mexico & - & Hindu \\
\hline E27. & Managing Director & Healthcare & Female & $36-40$ & 18 & 18 & Masters & - & Australia & 3 years & Hindu \\
\hline E28. & General Manager & Petroleum & Female & $41-45$ & 8 & 8 & Doctorate & - & USA & 4-5 months & Hindu \\
\hline E29. & $\begin{array}{l}\text { Senior General } \\
\text { Manager }\end{array}$ & $\begin{array}{l}\text { Business Services } \\
\text { (Consultancy) }\end{array}$ & Male & $51-55$ & 16 & 35 & Masters & - & - & - & Hindu \\
\hline E30. & $\begin{array}{l}\text { Senior Manager } \\
\text { Corporate } \\
\text { Communications }\end{array}$ & Coal Mining & Male & $51-55$ & 17 & 23.5 & Masters & - & - & - & Hindu \\
\hline E31. & $\begin{array}{l}\text { Senior Vice } \\
\text { President }\end{array}$ & $\begin{array}{l}\text { Manufacturing } \\
\text { (pipes/alloys) }\end{array}$ & Male & $51-55$ & 15 & 21 & Masters & USA & Germany and USA & 5 years & Muslim \\
\hline E32. & $\begin{array}{l}\text { Senior Vice } \\
\text { President } \\
\text { (Marketing) }\end{array}$ & $\begin{array}{l}\text { Information } \\
\text { Technology } \\
\text { Services }\end{array}$ & Male & $36-40$ & 12 & 16 & Masters & - & Australia and USA & Short trips & Parsi \\
\hline E33. & Head of Logistics & $\begin{array}{l}\text { Fast Moving } \\
\text { Consumer Goods }\end{array}$ & Male & $51-55$ & 5 & 30 & Bachelors & - & $\begin{array}{l}\text { USA and Several } \\
\text { European Countries }\end{array}$ & 2 years & Muslim \\
\hline E34. & $\begin{array}{l}\text { Managing } \\
\text { Director/Regional } \\
\text { Head }\end{array}$ & Manufacturing & Male & $46-50$ & 22 & 22 & Masters & USA & - & - & Parsi \\
\hline E35. & $\begin{array}{l}\text { Senior Vice } \\
\text { President } \\
\text { (Marketing) }\end{array}$ & $\begin{array}{l}\text { Information } \\
\text { Technology } \\
\text { Services }\end{array}$ & Male & $46-50$ & 2 & 25 & Masters & - & $\begin{array}{l}\text { Singapore, Korea, } \\
\text { Japan, USA, UK, } \\
\text { Australia }\end{array}$ & Short trips & Christian \\
\hline E36. & $\begin{array}{l}\text { Chief Financial } \\
\text { Oficer }\end{array}$ & Manufacturing & Male & $56-60$ & 10 & 35 & Masters & - & - & - & Christian \\
\hline E37. & Senior Editor & Media & Male & $36-40$ & 1 & 7 & Masters & Australia & - & - & Hindu \\
\hline
\end{tabular}




\begin{tabular}{|c|c|c|c|c|c|c|c|c|c|c|c|}
\hline E38. & $\begin{array}{l}\text { Head (Software } \\
\text { Design) }\end{array}$ & $\begin{array}{l}\text { Information } \\
\text { Technology }\end{array}$ & Male & $41-45$ & 15 & 24 & Masters & England & England & 2 years & Sikh \\
\hline E39. & $\begin{array}{l}\text { Vice President } \\
\text { (Corporate Cards) }\end{array}$ & Banking & Male & $46-50$ & 18 & 25 & Masters & - & - & - & Muslim \\
\hline E40. & Director (Human & Automobiles & Male & $51-55$ & 3 & 28 & Masters & - & - & - & Muslim \\
\hline
\end{tabular}




\section{Table 2: Schedule of questions}

1. What do you think make Indian business ethics unique? How is it different to business ethics in other countries? Please explain using examples.

2. What are some ethical principles that you are aware of in the Indian business context? Does your company apply any particular ethical principles? Please explain in detail.

3. Does your company apply the ethical principles that you identified in Q\#2 in every country they do business in? If yes, provide examples. If no, why and provide examples.

4. What are some ethical principles that you use in your day-to-day business interactions? Can you please provide examples?

5. Do you have a consistent guiding ethical principle(s) when dealing with all the stakeholders or do you apply different ethical principle(s) for different groups? Please give some examples.

6. How can Indian multinational businesses implement ethical practices? What do they need to do? Provide suggestions and examples.

7. How should Indian executives implement those ethical principles?

8. How do you implement those ethical principles?

9. How can executives develop an ethical mindset? Give examples and solutions.

10. Do you do anything personally to develop this ethical mindset?

11. How can multinational businesses develop an ethical mindset? Give examples and solutions. 
Table 3: An illustration of the open coding process

\begin{tabular}{|c|c|c|c|}
\hline Step 1: Underline key terms on the quotes & Step 2: Restating key phrases & $\begin{array}{l}\text { Step 3: Developing and } \\
\text { naming concepts }\end{array}$ & $\begin{array}{l}\text { Step 4: Developing and } \\
\text { naming categories }\end{array}$ \\
\hline $\begin{array}{l}\text { [E1] ... They follow law too much, they follow the personal side too much. They are more } \\
\text { process driven and we are only people driven. There is a substantial difference, so these are } \\
\text { the ways we take care of employees, employees have got their own welfare and measures, so } \\
\text { they can have what you call welfare societies, they are also treated with provident funds, } \\
\text { ESIC and whatever it takes, so many welfare measures are there. So this is how it stays } \\
\text { unique for the employees to be treated. And payment in time, granting loans and other things } \\
\text { with processes. For e.g. if there is an employee who wants to build his own flat or } \\
\text { construction of his own property, or get his daughter get married or do something like that, } \\
\text { we definitely help them... }\end{array}$ & $\begin{array}{l}\text { People driven } \\
\text { Take care of employees } \\
\text { Welfare measures } \\
\text { Help them }\end{array}$ & Empathy, sympathy and humanity & Ethical virtues \\
\hline
\end{tabular}

[E7]... Yes. We do not treat any agency house worse or better than the other. It's very fair to everyone. We really don't know whether there are any differences in the ethical principles being followed by the company in dealing with people in India and abroad. Because we really don't bother about what is being followed over there we tell them this is how ou business is run and you have to suite your business to suite our business.

[E18]... As I said we are doing all this confident and we are maintaining confidentiality of the reports, confidentiality of the client and the other thing is that we have adapted, as you know we have one hour software, computer technology, we use of computer technology in our system and one that ABS, so we are using this technology very nicely, we are adapted to this technologies and about client services and customer services, we are taking persona care. Our each and every employee is taking care of that person reports. Timely report and if there is anything requirement, our customer care are calling to those clients for those thing and they are trying to solve their problems... Society and nature what we do we do a lot of social activities. We do arrange for some payments for some societies like there are some organizations. It is very difficult for me to take the name of such organization because we keep it secret. There are a lot of NGO organizations where we do a lot of social work. Our company has done a lot of things for disabled persons and the things they have made shelter for them and all. To the health care they have done a lot of things. So those sort of things are tor them and

\section{Consistency}

Fairness
Justice and fairness

\section{Confidentiality}

Temperance and integrity

Sincerity and taking care of clients

Timely reporting

Solving clients problems

Social responsibility initiatives 
are uniform for all of us, it is not something that is flexible, and it has to be uniform throughout. While dealing with subordinates, I honor and I respect their position, I respect their work, definitely I don't cross my lines dealing with my juniors or my team members. Regarding ethical principle towards the company, I follow one policy; there should be transparency throughout all the levels. At all levels, we should be open for discussion, we should honor each other and we should respect everybody. While following the ethical principles towards the government, I told you already that we pay the taxes on time, we honor the policies which are imposed on us very strictly and we do honor each and every change which keeps on coming. So we maintain all those record all transparency in accounts everything is done.

[E20]... It is difficult, how do I explain that. I have always been known to my ethics. I an born and brought up in that way by my father. I do not make any extra effort it comes naturally. I have kept my needs and everything very low. I do not get influenced by the society like in terms of materialistic things, car and other things. I am not one who likes to buy fancy cars and I am satisfied with something which I have. I make a point that I don't get into office politics and other things which puts pressure on me. So, I just get busy in doing my work

[E2]... One has to study the situation in depth. I invite people for their views, and do the discussion and there after I come to the solution...In Ukraine and Malta, I first see the behavior, it all depends how much interest you take, if you leave everything on the subordinates then the things may be different, but I take personal interest in all the matter an this is why I devote more time to this. Another thing is that I always believe that the policie should be recommended by the people who are working in the field, and not by the people who are sitting in the $\mathrm{AC}$ chambers. I take the feedback from lower people and then dis with higher people, I invite the lower people while framing the policies then finalize it with their interest in mind because they are the implementers.

\section{Uniformity}

Transparency at all levels

Open discussion at all levels
[E1]... If I have the determination to practice ethical, nobody can collapse me, nobody can Determination touch me, nobody can influence me, nobody can twist me. If I don't have a determination, told you earlier also, individually the practices are important in India unlike other countries. Here an individual human beings has to be different in his approach and then only the ethica practices will survive, otherwise without ethical practices it will collapse, and basically the practices will surve, oill wave the determination yourself that I will not and basically the obstacle is that , you will have the determination yourself that I will not get corrupted or will not follow any unethical practice. So whatever odds that are going to be faced by me, so like that you have determination only, because now a days the people have become obstacles...Vendors may supply us some sub-standard quality of products, they may force you to accept. I should have a deternination to reject, I may even lose my job for should have a self-determination, without self-determination, nothing will work.

Setting standards

\section{Persistence}

Secure

Gratitude

usness and

transcendence

Hardworking

Curiosity

Wisdom

Learning and sharing

Personal interest

Open-mindednes
Leadership

Moral fortitude and determination 
Figure 1: A conceptual framework

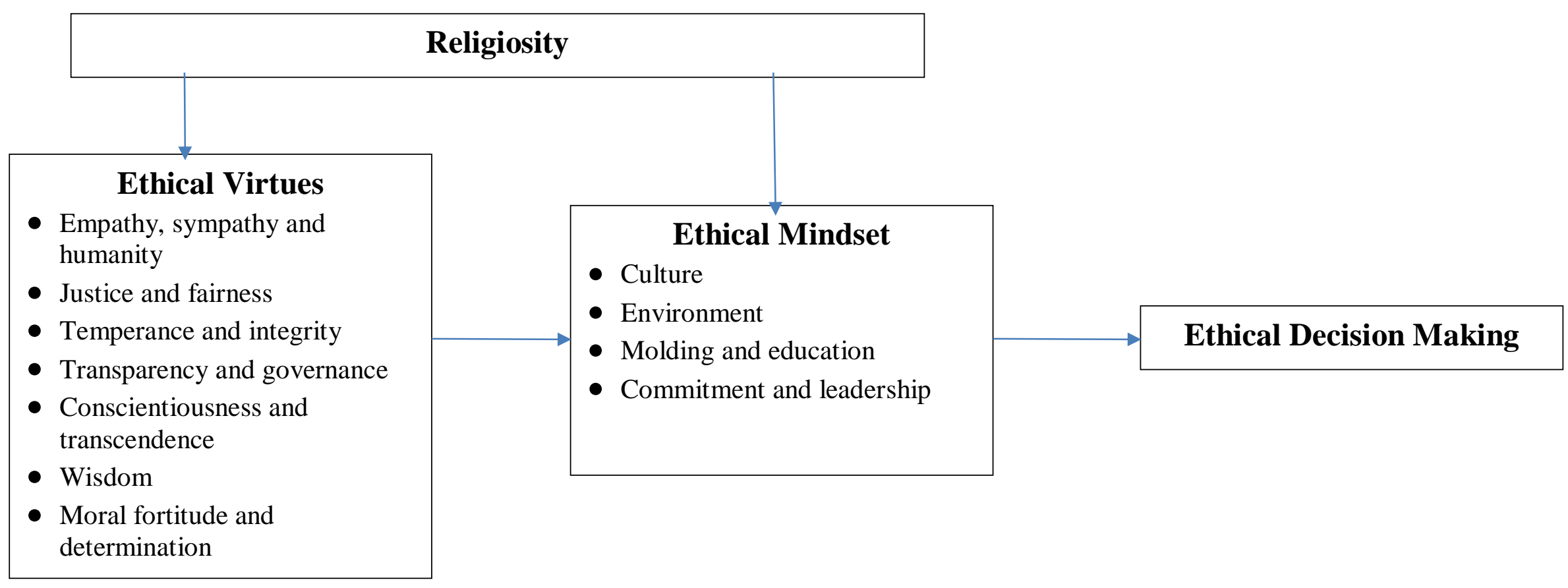

